*ak FMIS View/Frint Document Cover Sheet tow

This document was retrieved from the Documentation and Records Manaqement (DRM) ISEARCH System. It is intended for Information only and may not be the most recent or updated version. Contact a Document Service Center (see Hanford Info for locations) if you need additional retrieval information.

Accession \#: D196088855

Document \#: SD-WM-TI-744

Title/Desc:

METHODOLOGY FOR COMPLETING HANFORD 200 AREA TANK WASTE PHYSICAL \& CHEMICAL PROFILE ESTIMATIONS

Pages: 63 


\begin{tabular}{|l|l|}
\hline $\begin{array}{l}\text { 2. To: (Receiving organization) } \\
\text { Distribution }\end{array}$ & $\begin{array}{l}\text { 3. From: (Originating organization) } \\
\text { Evaluation and Planning }\end{array}$ \\
\hline 5. Proj./Prog./Dept./Div.: & $\begin{array}{l}\text { 6. Cog. Engr.: } \\
\text { E\&P/TB/TWRS }\end{array}$ \\
\hline
\end{tabular}

8. Originetor Remarks:

N/A
4. Relsted EOT No.:

$N / A$

7. Purchase Order No.:

N/A

9. Equip./Component No.:

$N / A$

10. Systen/Bldg./Facility: 2750E/200E

11. Receiver Remarks:

12. Major Assm. Dwg. No.: $N / A$

13. Permit/Permit Applicstion No.: N/A

14. Required Response Dete: $4 / 29 / 96$

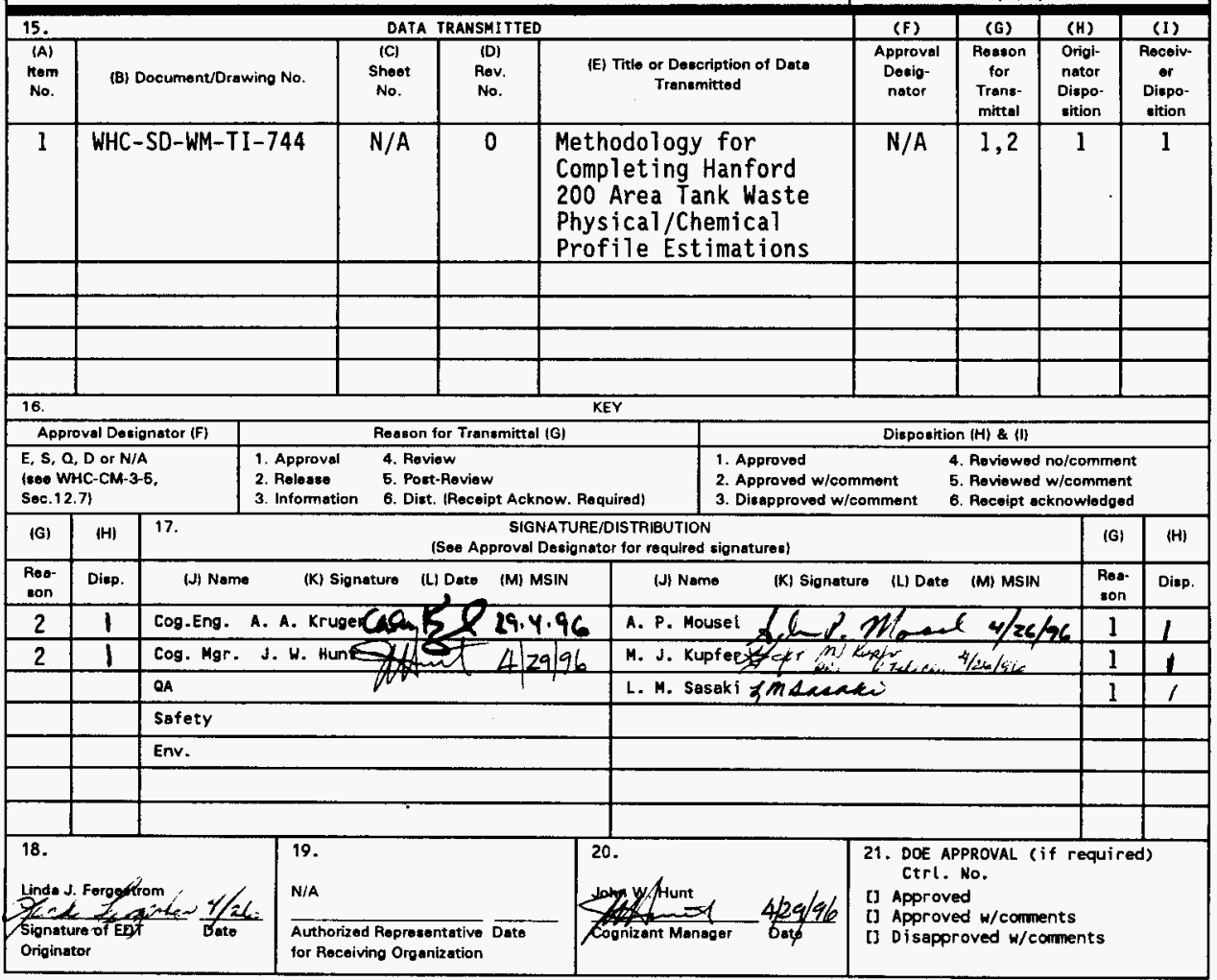




\title{
Methodology for Completing Hanford 200 Area Tank Waste Physical/Chemical Profile Estimations
}

\author{
Linda J. Fergestrom \\ Technical Resources International, Richland, WA 99352 \\ U.S. Department of Energy Contract DE-AC06-87RL10930
}

EDT/ECN: 615271

Org Code: 79200

B\&R Code: EW 3120074
UC: 2070

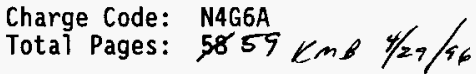

Key Words: Methodology, Waste Profiles, Waste Properties, Estimation

Abstract: The purpose of the Methodology for Completing Hanford 200 Area Tank Waste Physical/Chemical Profile Estimations is to capture the logic inherent to completing 200 Area waste tank physical and chemical profile estimates. Since there has been good correlation between the estimate profiles and actual conditions during sampling and sub-segment analysis, it is worthwhile to document the current estimate methodology.

TRADEMARK DISCLAIMER. Reference herein to any specific commercial product, process, or service by trade name, trademark, manufacturer, or otherwise, does not necessarily constitute or imply its endorsement, recommendation, or favoring by the United States Goverment or any agency thereof or its contractors or subcontractors.

Printed in the United States of America. To obtain copies of this document, contact: WHC/BCS Document Controt Services, P.O. Box 1970, Mailstop H6-08, Richland WA 99352, Phone (509) 372-2420; Fax (509) 376-4989.
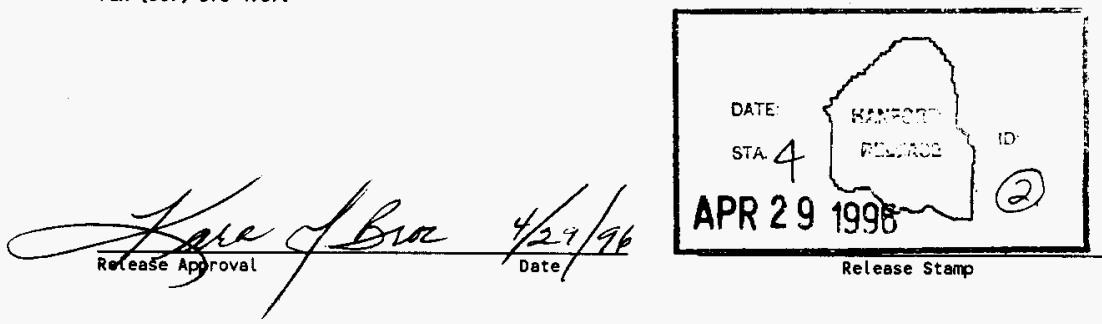

Release Stamp

Approved for Public Release 
WHC-SD-WM-TI-744, Rev. 0

\title{
Methodology for Completing Hanford 200 Area Tank Waste Physical/Chemical Profile Estimations
}

\author{
Linda $\mathbf{J}$. Fergestrom \\ Technical Resources International, Inc. \\ 723 The Parkway, Suite 200 \\ Richland, WA
}

April 29, 1996

Prepared for Westinghouse Hanford Company

Richland, WA 
Table of Contents

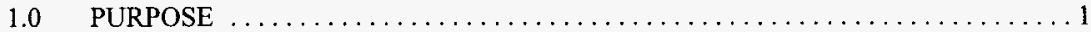

2.0 SCOPE OF PHYSICAL/CHEMICAL ESTIMATES AND RESPONSIBILITIES $\ldots \ldots 2$

3.0 BASIS AND STRUCTURE OF APPROACH $\ldots \ldots \ldots \ldots \ldots \ldots \ldots \ldots \ldots \ldots \ldots \ldots$

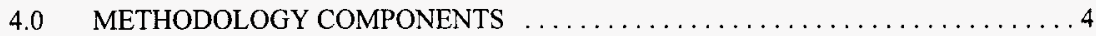

4.1 Establishing Requirements For A Baseline Estimate $\ldots \ldots \ldots \ldots \ldots \ldots \ldots$

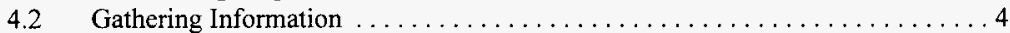

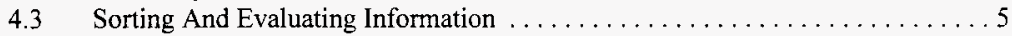

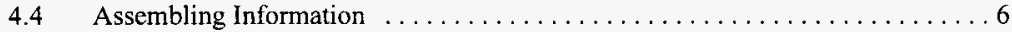

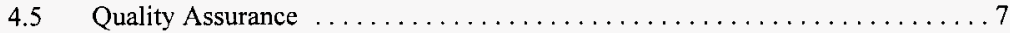

Table 1: Location of Physical/Chemical Profile Estimate Methodology Information $\ldots \ldots \ldots 8$

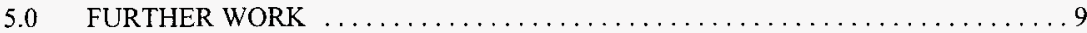

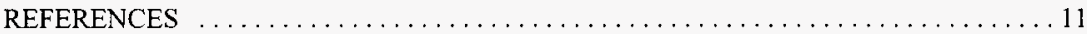

APPENDIX A:

Methodology for Hanford 200 Area Tank Waste Physical Profile Estimation

APPENDIX B:

Methodology for Hanford 200 Area Tank Waste Chemical Profile Estimation

APPENDIX C:

Baseline Bibliography Example for Physical/Chemical Profile Estimation

APPENDIX D:

200 Area Waste Tank Physical/Chemical Expected Profile Reference Checklist Sample

APPENDIX E:

Physical Profile Estimate Examples

APPENDIX F:

Chemical Profile Estimate Examples 
WHC-SD-WM-TI-744, Rev. 0

\subsection{PURPOSE}

This report was prepared for the Tank Waste Remediation System (TWRS) Characterization Program to document the methodology used to estimate physical and chemical profiles for the waste in 200 Area underground storage tanks. These estimates provide tank segment physical and chemical information to the project coordinators, and the sampling, transportation and laboratory staff that could impact the sampling schedule as well as the choice of sampling equipment, packaging and transportation equipment, and laboratory sample preparation equipment.

The TWRS Characterization Program is responsible for maintaining the historical physical and chemical data repository. Physical and chemical profile estimates compile this data to provide a comprehensive overview of the tank contents. Examples of physical and chemical information provided in the estimates are: sampling equipment obstacles, hard and soft layering in the waste, irregular crust level leading to poor or no sample recovery from different locations in the tank, and localized regions of high chemical and radionuclide content. This data can be provided to the project coordinators, sampling personnel, and laboratory staff for use in determining the appropriate sampling, shipping, and analytical methods for the tank or individual sample. In addition, these estimates can be recorded for each tank in the individual tank sampling and analysis plans.

This document establishes a baseline for the physical and chemical estimate methodology. To date, good correlation is found between the estimate profiles and actual conditions during sampling and sub-segment analysis. It should be noted that as more information is accumulated, the methodology will be improved and refined. Additional information is provided for further work to quantify the estimates derived from using the qualitative estimate methodology described in this document provided there is good correlation with the actual tank waste conditions. 


\subsection{SCOPE OF PHYSICAL/CHEMICAL ESTIMATES AND RESPONSIBILITIES}

Physical and chemical profile estimates are only valid prior to the sampling event for which they were created. A change in waste level, equipment added, equipment removed, or additional data available after the estimate is created may change the estimate results. In addition, the estimates cover only the liquid or solid waste in the waste tanks and do not include any predictions of tank dome space characteristics or any waste not within the waste tank, such as wastes that have leaked from the tanks.

Responsibilities are defined here for the physical and chemical profile estimate development and use. These estimates, prepared by TWRS Technical Basis Evaluation and Planning staff, are intended for use in the Technical Basis program and the Tank Characterization Project program. The primary physical and chemical profile estimate users are the tank project coordinators who are typically drawn from two groups: Technical Basis Evaluation and Planning and Data Assessment and Interpretation.

It is the responsibility of the Manager, TWRS Technical Basis Evaluation and Planning, or the appropriate designee to provide the estimates in a timely manner. As a general rule, an estimate should be provided to each data user, at a minimum, one week before the sampling event. To be incorporated into the individual tank sampling and analysis plans, the estimate may need to be completed up to two months ahead of the sampling event.

To maintain accuracy, maintain consistency, and integrate new informtion, a technical leader should be appointed to:

- oversee the baseline requirements and update/revise them as more information becomes available,

- $\quad$ see that the data for each estimate has been adequately gathered by himself or by a designee,

- review the evaluation technique for completeness,

- define a repository for all tables and graphical representations created,

- review the estimates for accuracy, consistency, and usability,

- help integrate information between similar efforts to use resources efficiently, and

- $\quad$ see that each estimate has been reviewed by a peer. 
WHC-SD-WM-TI-744, Rev. 0

\subsection{BASIS AND STRUCTURE OF APPROACH}

The process outlined in the next section gives a concise explanation of what tasks are required to compile an expected physical or chemical profile for any riser in any tank. Fundamental elements common for any estimate include:

- gathering all appropriate information,

- $\quad$ sorting and evaluating the information, and

- assembling the information into a consistent format (table, spreadsheet, or graphical representation).

Verification of the approach is accomplished by comparing the estimate against the actual sampling and chemical analysis data from the sampling event for which the estimate was developed.

It should be noted that the process for getting to a precise estimate is iterative. Thorough estimations demand assembling and segregating data from many tanks based on the type(s) of waste, and correlating that data to the tank or waste layer in question by looking at the current waste configuration and physical characteristics. 
WHC-SD-WM-TI-744, Rev. 0

\subsection{METHODOLOGY COMPONENTS}

The following methodology sections contain steps that span both physical and chemical profile estimate creation. Methodology components specific to either the physical or chemical profile estimates are contained in Appendices A and B, respectively. See Table 1 at the end of this section for location of specific components.

\subsection{Establishing Requirements For A Baseline Estimate}

A baseline must be established for each tank before more precise iterations can be performed. The first physical estimates done on a tank are considered part of the baseline which will remain valid until conditions in the tank change (ie. some or all of the waste is moved or waste is added) or until additional information is available that would cause a baseline revision. In order to establish this baseline, requirements must be set on the end product. These requirements are:

1. Estimate must contain information for each $30 \mathrm{~cm}$ (1 foot) section or $48 \mathrm{~cm}(19$ inch) segment for each riser potentially used for sampling. Multiple riser profiles within the same tank may be grouped if the information (including elevation information) is the same for all the risers in the group.

2. Estimate must contain information that is useful to the project coordinator, sampling, packaging and transportation, and/or laboratory staff. Details on information required for either a physical or chemical estimate can be found in Appendices A and B, respectively.

\subsection{Gathering Information}

Information gathering will be discussed in a generic fashion, since it is applicable to both physical and chemical estimates. There are three components of data gathering:

1. Creation of a baseline bibliography (where the relative validity of each document/media type in the bibliography is known):

An example of a baseline bibliography is given as Appendix $\mathrm{C}$, including comments on what kind of data can be expected from each source. It is the intent of the bibliography to include a majority of information that is applicable to a number of tanks, rather than to have all of the information for each tank. 
2. Gathering data relative to the tank in question:

Data needs to be gathered from both paper and electronic sources. In gathering the data for each tank, it is convenient to create a generic baseline reference checklist. The function of the generic baseline reference checklist is to provide a quick check-off reference list of the minimum data to be acquired for each tank. An example of a generic reference checklist is given in Appendix D.

In addition, the elevation at the bottom of the tank under each of the riser(s) potentially used for sampling should be calculated for tanks with a "dish" bottom. The elevation at the bottom of the tank under a riser can differ by as much as $30 \mathrm{~cm}$ (12 inches) from the bottom center elevation. For consistency, this elevation should be verified with the sampling truck cognizant engineer.

3. Assessing adequacy of the existing data and gathering additional data, if required:

A more extensive literature search may be needed if information is not readily available on a particular waste type or other issues specific to the tank. Many unique data sources are referenced on the baseline bibliography example found in Appendix C. If other unique data sources are found, they should be added to the baseline bibliography.

\subsection{Sorting And Evaluating Information}

The purpose of sorting and evaluating the data is to give the best estimate using all the available data. The quality and reliability of the evaluation will improve as more data is acquired about other tanks with similar waste types and waste layering chronology under similar physical conditions. Sorting and evaluating the information consists of:

1. Reviewing all recorded media for content:

Media are reviewed and sorted by their level of importance to accomplish either the physical or chemical estimate task.

2. Identifying key documents in information gathered:

Key media are identified to best support the physical or chemical estimate. Here the data is evaluated for reliability and validity as well as content applicability. 
3. Assessing current tank waste characteristics (ie. what kind of waste was added under what conditions and what is still present):

a. Current model waste types projected for a tank are evaluated against any sample physical characteristics or chemical analyses. Physical characteristics for each waste type are evaluated and (if non-existent) developed.

b. Waste layers with their waste type and characteristics are proposed. The waste layer is evaluated for any potential physical property or chemical composition changes due to irregular layering.

Checking with 200 Area tank characterization, cognizant, field, and process engineers on the validity of assumptions is recommended. If the data for a given waste type needs refinement, or a different waste type should be allocated for a waste layer, those recommendations will be noted and the reason stated. In addition, layers that may be significantly affected by a system or sampling bias, such as the crust layer and high liquid content layers should be noted.

4. Noting physical structures and chemical configurations on top of waste or anomalies under risers:

All information on the configuration or characteristics of the top of the waste is pulled from the key media. Examples of the data gathered include:

- location, irregularity, height, and composition of crystal structures or floating organic layers,

- existence of FIC tapes or rocks under a riser potentially used for sampling, and

- disturbances in the waste surface due to existing or removed equipment.

5. Associating physical properties or chemical constituents to the waste layers and segments under each riser potentially used for sampling.

Elevation boundaries are established for the waste layers. The characteristics for each waste layer are defined between the elevation boundaries. These boundaries are also used when projecting waste characteristics for each $30 \mathrm{~cm}$ (1 foot) section or $48 \mathrm{~cm}$ (19 inch) segment. 


\subsection{Assembling Information}

Assembling the data consists of constructing the tables or graphical representations of the physical or chemical information for each $30 \mathrm{~cm}$ (foot) section or $48 \mathrm{~cm}$ (19 inch) segment. Segments are defined by elevation where the last segment in a core sample is at the bottom of the tank. Since this is the case, it is good to note that the first segment in a core sample may or may not be full of waste. Characteristics for each $30 \mathrm{~cm}$ (1 foot) section or $48 \mathrm{~cm}$ (19 inch) segment are divided by waste layer elevation boundary. Therefore, one segment could be broken into many elevation bounded characteristic sets or many segments may have the same set of characteristics. Detail on what should be included in each table or graphical representation can be found in the physical and chemical estimate methodologies, Appendices A and B, respectively. Examples of physical profile estimates can be found in Appendix $E$ and for chemical profile estimate in Appendix F.

\subsection{Quality Assurance}

All assumptions made in developing the estimates shall be recorded on the table or in the graphical representation. Each estimate should be reviewed by peers to assist in resolving syntax and grammatical problems, as well as meeting the requirements found in section 4.1 , thereby achieving the best possible product. 
Table 1: Location of Physical/Chemical Profile Estimate Methodology Information

\begin{tabular}{|c|c|c|c|}
\hline Section & Section TitlefDescription of Baseline Profile Element & Physical Profile & Chemical Profile \\
\hline $4.1-4.5$ & General Location of Methodology Information on Profile & Appendix A & Appendix B \\
\hline 4.1 & Establish Baseline Profile Requirements & A.1 & B.1 \\
\hline 4.2 & Gather Appropriate Information & A.2 & B.2 \\
\hline \multirow[t]{2}{*}{4.2 .1} & Create Bibliography & A.2.1 & B.2.1 \\
\hline & - Bibliography Example & Appendix C & Appendix C \\
\hline \multirow[t]{2}{*}{4.2 .2} & Gather Data & A. 2.2 & B.2.2 \\
\hline & - Sample Reference Checklist & Appendix D & Appendix D \\
\hline 4.2 .3 & Assess Adequacy of Data & A.2.3 & B.2.3 \\
\hline 4.3 & Sort and Evaluate Information & A.3 & B.3 \\
\hline 4.3 .1 & Review all documents/media for content & A.3.1 & B.3.1 \\
\hline 4.3 .2 & Identify key documents & A. 3.2 & B.3.2 \\
\hline 4.3 .3 & Assess current tank waste characteristics & A. 3.3 & B.3.3 \\
\hline 4.3 .4 & Note physical structures/anomalies and chemical configurations & A.3.4 & A.3.4 \\
\hline 4.3 .5 & Associate physical/chemical information to waste layers/segments & A.3.5 & B.3.5 \\
\hline \multirow[t]{2}{*}{4.4} & Assembling Information & A.4 & B.4 \\
\hline & - Examples of Estimates & Appendix E & Appendix $\mathrm{F}$ \\
\hline 4.5 & Quality Assurance & - & - \\
\hline
\end{tabular}


WHC-SD-WM-TI-744, Rev. 0

\subsection{FURTHER WORK}

To more accurately predict the physical properties and chemical constituents in each of the tanks, information can be gathered from various sources and compared. Since the first estimate is to be used as a baseline, improving the accuracy of the estimate requires that the estimate gives a good representation of the actual physical conditions or chemical composition. If no correlation can be drawn between estimate and actual conditions, either more data is needed to create a new baseline, or a determination made that the physical/chemical characteristics in the tanks can not be estimated. Some of the options for improving the estimates beyond the initial baseline are listed below.

1. Investigate physical properties and chemical constituents in tanks where waste types have previously been sampled. See if there are any similarities between tanks that contain the same waste type by correlating the physical properties per waste layer and chemical concentration per waste type. This would be done on waste types and waste layers before the information is incorporated into an estimate.

2. Compare physical and chemical profile estimates with actual data from the sampling or laboratory staff for a number of tanks. Assess conformity of estimate to actual data to determine if the current estimates and historical data used in the estimates can be used, or if a significant amount of additional data is required to rebaseline.

3. The correlation between the physical or chemical profile estimates and segment averages can be computed. This correlation can be used to test "agreement" between the two methods.

4. Develop a consistent format to use when presenting estimate results.

5. As other characterization or other program needs are identified, changes may need to be incorporated into the methodology to meet those needs, such as different information needs for various sampling methods.

6. Acquire model inventory calculation spreadsheet (such as Microsoft Excel version 5 file "estimate.r 3 " used for calculating inventory estimates from Los Alamos National Laboratory) and compare the Hanford Defined Waste (Agnew, 1995) estimates with those generated by the spreadsheet for each tank waste layer. The chemical analyte and radionuclide values for each waste layer in an individual tank can be derived from the spreadsheet and compared to HDW reported values. 
WHC-SD-WM-TI-744, Rev. 0

7. Check the inventory estimates (such as (Brevick, 1994a,b) and (Brevick 1995a,b)) for the non-supernatant layer with the total waste minus the supernatant layer separated by Hanford Defined Waste (Agnew, 1995) waste type. This will help determine consistency in the model and help to assign waste types to unknown layers.

8. Compare tank groups as defined by K. M. Remund, C. M. Anderson and B. C. Simpson with field sampling data to see if there is a correlation between tank groups and physical waste characteristics.

9. Other sources of data may be added extending or updating the current bibliography. 


\section{REFERENCES}

Agnew, S. F., Sept. 1995, Hanford Defined Wastes: Chemical And Radionuclide Compositions, LA-UR-94-2657, Rev. 2, Los Alamos National Laboratory, Los Alamos, New Mexico.

Brevick, C.H., et al., 1994a, Historical Tank Content Estimate for the Northeast Quadrant of the Hanford 200 Areas, WHC-SD-WM-ER-349, Rev. 0A, Westinghouse Hanford Company, Richland, Washington.

Brevick, C.H., et al., 1995a, Historical Tank Content Estimate for the Northwest Quadrant of the Hanford 200 Areas, WHC-SD-WM-ER-351, Rev. 0, Westinghouse Hanford Company, Richland, Washington.

Brevick, C.H., et al., 1995b, Historical Tank Content Estimate for the Southeast Quadrant of the Hanford 200 Areas, WHC-SD-WM-ER-350, Rev. 0, Westinghouse Hanford Company, Richland, Washington.

Brevick, C.H., et al., 1994b, Historical Tank Content Estimate for the Southwest Quadrant of the Hanford 200 Areas, WHC-SD-WM-ER-352, Rev. 0A, Westinghouse Hanford Company, Richland, Washington.

WHC 1996, Unclassified Operating Specifications For Single-Shell Waste Storage Tanks, OSDT-151-00013, Rev. D-10, Westinghouse Hanford Company, Richland, Washington. 
WHC-SD-WM-TI-744, Rev. 0

\section{Appendix A}

\section{Methodology for Hanford 200 Area Tank Waste Physical Profile Estimation}

$$
\text { A - } 0
$$


WHC-SD-WM-TI-744, Rev. 0

\section{Appendix A Methodology Components for Creating a Physical Profile Estimate}

\section{A.1 Establishing requirements for a physical profile estimate}

Requirements specific to creating a physical profile estimate are defined as follows:

1. Estimate must contain information for each $30 \mathrm{~cm}$ (foot) section or $48 \mathrm{~cm}(19$ inches) segment for each riser potentially used for sampling. Riser profiles for the same tank may be grouped if the information is the same for all the risers in the group.

2. Estimate must contain information that is useful to the project coordinator, and the sampling, packaging and/or transportation staff. Specifically, the information required (hereafter denoted as physical properties) for each riser is:

a. A determination of waste layers as hard or soft, where hard and soft can be correlated to amount of downward force from the coring equipment necessary to retrieve samples.

b. A determination of physical waste consistency per layer: saltcake, slurry, sludge.

c. Identification of waste surface characteristics: liquid, solid, crust, miscellaneous other equipment, rocks, etc.

d. A determination of wet and dry layers.

\section{A.2 Gathering information}

Information gathering should be performed prior to establishing a physical profile and is therefore discussed in the main body of this document. Information available at the time of physical profile estimate creation should be:

1. A baseline bibliography (such as the one included in Appendix C).

2. A folder containing data relative to the tank in question. 
WHC-SD-WM-TI-744, Rev. 0

\section{A.3 Sorting and evaluating information}

Sorting and evaluating the information for creation of a physical profile consists of:

1. Reviewing all media for content:

Media are reviewed and sorted by their applicability and validity regarding the creation of a physical profile for the tank.

2. Identifying key media in information gathered:

Media specifically related to the waste types and physical properties in the tank in question are selected as key documents and rated for information quality (reliability and validity).

\section{Assessing current waste characteristics:}

Simultaneous evaluation of the current model waste types and the physical properties of the waste is an essential part of creating a physical profile estimate. Current model waste types per tank are evaluated to see if the same divisions used for separating waste types can be used to associate physical characteristics with a given waste layer.

Evaluating and assigning physical properties to waste layers in the tank consists of looking at the waste level history and allocating physical characteristics to waste layers. Layers marked unknown are evaluated to find the closest waste layer approximation. Some of the inputs to the evaluation are: fill, solids level, liquid level, and temperature history, and physical properties on tank waste sample analyses. Knowledge of crystal growth science is very beneficial when determining physical characteristics for waste layers that have developed over time and temperature changes. Specific items to address are given below:

a. Establish and (if non-existent) develop physical characteristics for each waste type.

b. Evaluate any additional data (such as sample analyses) taken from the tank against physical properties associated with the corresponding waste type.

c. Evaluate any additional physical properties of the waste specific to the tank in question due to irregular layering.

d. Evaluate rapid temperature changes affecting waste precipitation or due to waste addition or removal.

$$
\text { A - } 2
$$


WHC-SD-WM-TI-744, Rev. 0

\section{A.3 Sorting and evaluating information (cont.)}

e. Evaluate significant $\mathrm{pH}$ changes that could affect waste precipitation.

f. Evaluate the effect of processes such as evaporator campaigns, saltwell screens, air lift circulators, etc. on waste characteristics.

g. Evaluate the effect of high radionuclide or metal content concentration(s) based on applicable chemical analyses.

h. Resolve discrepancies between data sources by using the most recent data or data that is representative of the current tank content.

i. Establish waste layering estimate based on waste type chronology and factors addressed in (a) through $(\mathrm{h})$.

4. Noting physical structures on top of waste or anomalies under riser in question:

All information on the configuration or characteristics of the top of the waste is acquired from the key media. Examples of the data gathered include:

- location, irregularity, and height of physical structures, and

- existence of FIC tapes or rocks under a riser to be sampled.

5. Associating physical properties to the waste layers and segments under each riser potentially used for sampling:

To associate physical properties to the waste layers, the waste layers need to be dimensionally bounded as they are in the field. Elevations are calculated at the top and bottom of each waste layer. The physical properties defined in step 3 are associated with the waste in the tank between the elevation boundaries for that specific waste layer. These boundaries are also used when projecting physical properties for each 30 $\mathrm{cm}$ (1 foot) section or $48 \mathrm{~cm}$ (19 inch) segment.

\section{A.4 Assembling information}

Assembling the data consists of constructing the tables or graphical representations of the physical information by either $30 \mathrm{~cm}$ (1 foot) sections or $48 \mathrm{~cm}$ ( 19 inch) segments. The layering of waste based on physical property boundaries is then correlated to the sampling sections or segments in the core sampling process. Any physical anomalies associated with the riser in question are noted on the table or graphical representation. For examples of physical profile estimates, see Appendix E. 
WHC-SD-WM-TI-744, Rev. 0

\section{Appendix B}

Methodology for Hanford 200 Area Tank Waste Chemical Profile Estimation

B - 0 
WHC-SD-WM-TI-744, Rev. 0

\section{Appendix B \\ Methodology Components for Creating a Chemical Profile Estimate}

\section{B.1 Establishing requirements for a baseline estimate}

Requirements specific to creating a chemical profile estimate are defined as follows:

1. Estimate must contain information for each $30 \mathrm{~cm}$ (1 foot) section or per $48 \mathrm{~cm}$ (19 inch) segment for each riser potentially used for sampling. Riser profiles for the same tank may be grouped if the information is the same for all the risers in the group.

2. Estimate must contain information that is useful to the project coordinator, and the packaging, transportation, and laboratory staff. Specifically, the information required (hereafter denoted as chemical constituents) for each riser is:

a. A determination of chemical concentration and radionuclide content reporting limits for each waste layer for the estimate. This is a concentration or value where any chemical analyte or radionuclide with a value above this limit is reported on the chemical profile estimate table.

b. A determination of chemical analytes and radionuclides from all available data that exceed established limit in (a) for each segment.

\section{B.2 Gathering information}

Information gathering should be performed prior to establishing a physical profile and is therefore discussed in the main body of this document. Information available at the time of chemical profile estimate creation should be:

1. A baseline bibliography (such as the one included in Appendix C).

2. A folder containing data relevant to the tank in question.

3. A physical profile estimate (optional). 
WHC-SD-WM-TI-744, Rev. 0

\section{B.3 Sorting and evaluating information}

Sorting and evaluating the information for creation of a chemical profile consists of:

1. Reviewing all media for content:

Media are reviewed and sorted by their applicability and validity regarding the creation of a chemical profile for the tank.

2. Identifying key media in information gathered:

Media specifically related to the waste types and chemical properties in the tank in question are selected as key documents and rated for information quality.

3. Assessing current waste characteristics:

At this time, a fairly simple method is used for evaluating high chemical concentrations and radionuclide content for each waste layer. Current waste layer information (from physical profile estimate or done independently) per tank is coupled with any applicable chemical analysis (with sample location, if available) and any model estimate of chemical constituents per waste type. Specific items to address are given below:

a. Determine waste layer elevation boundaries for the tank in question (The physical profile estimate contains the methodology for completing this process in step 3 (a)-(h) of Appendix A).

b. Enter or electronically incorporate information from any whole tank, waste layer, or other chemical analysis into a spreadsheet, database or other appropriate electronic form. At this time, whole tank and composite sample analyses are evaluated against data specific to each waste layer in the tank. Analyses that do not include the location in the tank where the sample was taken are estimated to be in a waste layer based on general information of tank contents relevant to the time the sample was taken. 


\section{B.3 Sorting and evaluating information (cont)}

c. Resolve discrepancies between media sources by using the most reliable and chemically feasible data. The latest raw analytical data should be used. This assumes that corrections made to analytical data were made in the latest distributed data. Sample analysis compilations should be checked carefully against the referenced raw data. If there are any discrepancies, the raw data should be used. Information from models are used without modifications, though there may be discrepancies in the model assumptions as compared against historical process stream information.

c. Establish consistent units for all chemical and radionuclide data (ie. Moles/Liter for chemical analytes and $\mathrm{Bq} / \mathrm{L}$ for radionuclides).

\section{d. Decay radionuclides to the current year.}

e. Establish chemical concentration and radionuclide content reporting limits to be used in developing the chemical profile estimate. An example of the limits used per waste layer are:

- all chemical constituents above $0.1 \mathrm{~mol} / \mathrm{L}$ (designating the chemical analytes with the highest concentration),

- all major alpha emitters above $2.27 \mathrm{E}+08 \mathrm{~Bq} / \mathrm{L}(6.14 \mathrm{E}+03 \mathrm{uCi} / \mathrm{L}$ ) (one tenth of the value listed in (WHC 1996)),

- $\quad \mathrm{Cs}-137$ content above $1.2 \mathrm{E}+09 \mathrm{~Bq} / \mathrm{L}(3.28 \mathrm{E}+05 \mathrm{uCi} / \mathrm{L}$ ) (one tenth of the value listed in (WHC 1996)), and

- Sr-90 content above $8.51 \mathrm{E}+08 \mathrm{~Bq} / \mathrm{L}(2.30 \mathrm{E}+04 \mathrm{uCi} / \mathrm{L})$ (one tenth of the value listed in (WHC 1996)).

f. Determine which chemical analytes or radionuclides exceed the chemical concentration and radionuclide content estimate reporting limits either from analysis or model estimate per waste layer.

4. Noting chemical configurations on top of waste under riser in question:

All information on the configuration or characteristics of the top of the waste is retreived from the key media. Examples of the data gathered include:

- chemical composition of crystal structure, and

- existence of floating organic layer. 


\section{B.3 Sorting and evaluating information (cont.)}

5. Associating chemical constituents to the waste layers:

The chemical constituents defined in step 3 (f) for each waste layer are associated with the waste in the tank between the elevation boundaries for that specific waste layer as defined in step 3 (a). These boundaries are also used when projecting chemical constituents for each $30 \mathrm{~cm}$ (1 foot) section or $48 \mathrm{~cm}$ (19 inch) segment.

\section{B.4 Assembling information}

Assembling the data consists of constructing the tables or graphical representations of the chemical information by either $30 \mathrm{~cm}$ ( 1 foot) sections or $48 \mathrm{~cm}$ (19 inch) segments. The layering of waste based on chemical constituent boundaries is then correlated to the sampling sections or segments in the core sampling process. Any chemical configurations are noted in a comments column associated with the appropriate segment. For examples of chemical profile estimates, see Appendix F. 
WHC-SD-WM-TI-744, Rev. 0

\section{Appendix C}

\section{Baseline Bibliography Example \\ for Physical/Chemical Profile Estimation}

$$
\text { C - } 0
$$


WHC-SD-WM-TI-744, Rev. 0

\section{Appendix C \\ Baseline Bibliography Example for Physical/Chemical Profile Estimation}

Appendix C provides a bibliography of information that supports Westinghouse Hanford Company Tank Waste Remediation System Characterization Program. The references in this bibliography are separated into three broad categories with references contained in subgroups. These categories and their subgroups are listed below.

I. Non-Analytical Data

Ia. Models/Waste Type Inventories/Campaign Information

Ib. Fill History/Waste Transfer Records

Ic. Surveillance/Tank Configuration

Id. Sample Planning/Tank Prioritization

le. Data Quality Objectives/Customers of Characterization Data

If. Other - non/documented or electronic sources

II. Analytical Data

IIa. Sampling of Tank Waste and Waste Types

IIb. Other - non/documented or electronic sources

III. Combined Analytical/Non-Analytical Data

IIIa. Inventories using both Campaign and Analytical Information

IIIb. Compendium of Existing Physical and Chemical Documented Data Sources

IIIc. Other - non/documented or electronic sources

IV. Other Documented Resources

For brevity and ease of use, the references and locations cited here are intended to be general starting points. Tank specific information is not listed here. Pertinent example references are given in each subgroup below. Some of the references may be listed in more than one section for completeness. However, since this bibliography is to be used as an example, other references and categories may need to be added under the subgroups as the profile estimates are developed. 


\section{Non-Analytical Data}

Ia. Models/Waste Type Inventories/Campaign Information

Anderson, J.D., A History of the 200 Area Tank Farms, WHC-MR-0132, Jun. 1990 , Westinghouse Hanford Company, Richland, WA.

- Document contains single-shell tank fill history and primary campaign/waste type information up to 1981 .

Boldt, A. L., Redox Chemical Flowsheet $H W$ No. 9, ISO-335, 1966, Isochem, Inc., Richland, WA.

- Document contains compositions of material balance for Redox process as well as a separations plan denoting process stream waste before transfer to 200 Area waste tanks.

Borsheim, G.L., B.C. Simpson, An Assessment of the Inventories of the Ferrocyanide Watchlist Tanks, WHC-SD-WM-ER-133, Rev. 0, Oct 1991, Westinghouse Hanford Company, Richland, WA.

- Document contains estimations of $\mathrm{Fe}(\mathrm{CN})_{6}{ }^{-4}, \mathrm{Cs}-137$, and Sr-90 for various ferrocyanide containing tanks.

Crawley, D. T., Redox Chemical Flowsheet HW-No. 6, HW-66203, 1960, Hanford Atomic Products Operation, General Electric Company, Richland, WA.

- Document contains compositions of material balance for Redox process as well as a separations plan denoting process stream waste before transfer to 200 Area waste tanks.

Jungfleisch, F.M., B.C. Simpson, Preliminary Estimation of the Waste Inventories in Hanford Tanks Through 1980, SD-WM-TI-057 Rev. 0-A, Oct 1993, Westinghouse Hanford Company, Richland, WA.

- A model based on process knowledge and radioactive decay estimations using ORIGEN for different compositions of process waste streams assembled for total, solution, and solids compositions per tank. Assumptions about waste/waste types and solubility parameters/constraints are also given.

C - 2 
Merrill, E. T., and R. L. Stevenson, REDOX Chemical Flowsheet HW No. 5, HW-38684, 1955, Hanford Atomic Products Operation, Richland, WA.

- Document contains compositions of material balance for Redox process as well as a separations plan denoting process stream waste before transfer to 200 Area waste tanks.

Schneider, K.J., Flowsheets and Flow Diagrams of Precipitation Separations Process, HW23043, Dec. 17, 1951, Hanford Atomic Products Operation, Richland, WA.

- Document contains compositions of process stream waste before transfer to 200 Area waste tanks.

Sloat, R. J., TBP Plant Nickel Ferrocyanide Scavenging Flowsheet, HW-30399, 1954, General Electric Company, Richland, WA.

- Document contains compositions of process stream waste before transfer to 200 Area waste tanks. 
Ib. Fill History/Waste Transfer Records

Agnew, S. F., R. Corbin, T. Duran, K. Jurgensen, T. Ortiz, and B. Young, WSTRS Rev. 2:

Supernatant Mixing Model (SMM) Tank Layer Model (TLM), LA-UR-94-4269, Rev. 2, Oct. 1995, Los Alamos National Laboratory, Los Alamos, New Mexico.

- Document gives scaled down WSTRS spreadsheets with the primary wastes per tank.

Agnew, S.F., R. A. Corbin, T. B. Duran, K. A. Jurgensen, T. P. Ortiz, and B. L. Young, Waste Status and Transaction Record Summary for the Northeast Quadrant, WHC-SD-WM-TI615, Rev. 1, Jan. 26, 1996, Los Alamos National Laboratory, Los Alamos, New Mexico.

- Document contains spreadsheets depicting all available data on tank additions/transfers for NE quadrant.

Agnew, S.F., R. A. Corbin, T. B. Duran, K. A. Jurgensen, T. P. Ortiz, and B. L. Young, Waste Status and Transaction Record Summary for the Northwest Quadrant, WHC-SD-WMTI-669, Rev. 1, Jan. 26, 1996, Los Alamos National Laboratory, Los Alamos, New Mexico.

- Document contains spreadsheets depicting all available data on tank additions/transfers for NW quadrant.

Agnew, S.F., R. A. Corbin, T. B. Duran, K. A. Jurgensen, T. P. Ortiz, and B. L. Young, Waste Status and Transaction Record Summary for the Southeast Quadrant, WHC-SD-WM-TI689, Rev. 1, Jan. 26, 1996, Los Alamos National Laboratory, Los Alamos, New Mexico.

- Document contains spreadsheets depicting all available data on tank additions/transfers for SE quadrant.

Agnew, S.F., R. A. Corbin, T. B. Duran, K. A. Jurgensen, T. P. Ortiz, and B. L. Young, Waste Status and Transaction Record Summary for the Southwest Quadrant, WHC-SD-WM-TI614, Rev. 1, Jan. 26, 1996, Los Alamos National Laboratory, Los Alamos, New Mexico.

- Document contains spreadsheets depicting all available data on tank additions/transfers for SW quadrant.

Anderson, J.D., A History of the 200 Area Tank Farms, WHC-MR-0132, Jun 1990, Westinghouse Hanford Company, Richland, WA.

- Document contains single-shell tank fill history and primary campaign/waste type information up to 1981 . 
WHC-SD-WM-TI-744, Rev. 0

Ic. Surveillance/Tank Configuration

Alstad, A. T., Riser Configuration Document for Single-Shell Waste Tanks, SD-RE-TI-053, Rev. 9, Dec. 17, 1993, Westinghouse Hanford Company, Richland, WA.

- Document shows tank riser locations in relation to tank aerial view as well as a description of riser and its contents.

Lipnicki, J., Waste Tank Risers Available for Sampling, WHC-SD-WM-TI-710, Rev. 1, Dec. 20, 1995, Rev. 2, Westinghouse Hanford Company, Richland, WA.

- Document gives an assessment of all risers per tank, however not all tanks are included/completed.

Salazar, B. E., Double-Shell Underground Waste Storage Tanks Riser Survey, WHC-SD-RE-TI093, Rev. 4, May 23, 1994, Westinghouse Hanford Company, Richland, WA.

- Document shows tank riser locations in relation to tank aerial view as well as a description of riser and its contents. 
WHC-SD-WM-TI-744, Rev. 0

Id. Sample Planning/Tank Prioritization

Brown, T.M., Tank Waste Characterization Basis, WHC-SD-WM-TA-164, Rev.0, Aug. 31, 1995, Westinghouse Hanford Company, Richland, WA.

- Document that summarizes the technical basis for characterizing the waste in the tanks and assigns a priority number to each tank.

Grimes, G.W., Hanford Long-Term Defense High-Level Waste Management Program Waste Sampling and Characterization Plan, RHO-CD-137, Oct. 1977, Rockwell Hanford Operations, Richland, WA.

- Document contains plan for characterizing waste, short and long term goals, tank priority, analysis needs, estimates of analyte concentrations per waste type, and a characterization flowsheet.

Homi, C.S., et al., Fiscal Year 1996 Tank Waste Analysis Plan, WHC-SD-WM-PLN-101, Rev. 0, Aug. 28, 1995, Westinghouse Hanford Company, Richland, WA.

- Document contains TPA requirement driven TWRS Characterization program information and a list of tanks addressed in fiscal year 1996.

C -6 
Ie. Data Quality Objectives/Customers of Characterization Data

Dukelow, G. T., J. W. Hunt, H. Babad, and J. E. Meacham., Tank Safety Screening Data Quality Objective, WHC-SD-WM-SP-004, Rev 2, Aug. 31, 1995, Westinghouse Hanford Company, Richland, WA.

- Document contains objectives to sample all tanks for safety concerns (ferrocyanide, organic, flammable gas, and criticality) as well as decision thresholds for energetics, criticality and flammability.

Fowler, K. D., Data Quality Objectives for Tank Farms Waste Compatibility Program, WHCSD-WM-DQO-001, Rev. 1, Westinghouse Hanford Company, Richland, WA.

- Document contains waste transfer compatibility program data needs, list of tanks to be evaluated, decision thresholds, and decision logic flow diagram.

Kupfer, M.J., Strategy for Sampling Hanford Site Tank Wastes for Development of Disposal Technology, WHC-SD-WM-TA-154, Rev. 1, Jun. 29, 1995, Westinghouse Hanford Company, Richland, WA.

- Document contains sample strategy to meet pretreatment and disposal data needs and list of tanks to be evaluated.

McDuffie, N. G., Flammable Gas Tank Safety Program: Data Requirements for Core Sampling analysis Developed Through the Data Quality Objectives Process, WHC-SD-WM-DQO004, Rev. 2, July 1995, Westinghouse Hanford Company, Richland, WA.

- Document contains flammable gas program data needs, list of tanks to be evaluated, decision thresholds, and decision logic flow diagram.

Meacham, J.E., et al., Data Requirements for the Ferrocyanide Safety Issue Developed Through the Data Quality Objective Process, WHC-SD-WM-DQO-007, Rev. 2, Jul. 6, 1995, Westinghouse Hanford Company, Richland, WA.

- Document contains ferrocyanide program data needs, list of tanks to be evaluated, decision thresholds, and decision logic flow diagram.

Simpson, B.C. and D. J. McCain, Historical Model Evaluation Data Requirements, WHC-SDWM-DQO-018, Rev 0-A, Oct. 3, 1995, Westinghouse Hanford Company, Richland, WA.

- Document identifies analytical parameters to characterize waste into one of five waste types. 
Slankas, T.J., et al., Data Needs and Attendant Data Quality Objectives for Tank Waste Pretreatment and Disposal, WHC-SD-WM-DQO-022, Rev. 0, Jun. 29, 1995, Westinghouse Hanford Company, Richland, WA.

- Document contains data needs for pretreatment and disposal including information on sludge washing, solid/liquid separation, and $\mathrm{Cs}$, $\mathrm{Sr}$, and TRU removal.

Turner, D.A., et al., Data Quality Objective to Support Resolution of the Organic Complexant Safety Issue, WHC-SD-WM-DQO-006, Rev. 2, Sept. 8, 1995, Westinghouse Hanford Company, Richland, WA.

- Document contains organic program data needs, list of tanks to be evaluated, decision thresholds, and decision logic flow diagram.

Von Bargen, B. H., 242-A Evaporator/Liquid Effluent Retention Facility Data Quality Objectives, WHC-SD-WM-DQO-014, Rev. 1, Apr. 25, 1995, Westinghouse Hanford Company, Richland, WA.

- Document contains 242-A Evaporator/LERF program data needs, list of tanks to be evaluated, decision thresholds, and decision logic flow diagram. 
WHC-SD-WM-TI-744, Rev. 0

If Qther-non/documented or electronic sources

McCain, D.J., Characterization Status Table (aka. Characterization Progress Data Report), Mar. 12, 1996, In: Hypertext Mark-Up Language (HTML), Available:

http://www.hanford.gov/TWRS/char.pub/progdata.htm

- Table reports watchlist, Characterization Basis, and DQO applicability, and characterization status per tank; updated weekly.

Westinghouse Hanford Company (WHC) 1996. Cog Engineer's Tank Sampling Field Data. In: Hardcopy. Available: WHC, 200E, 2704HV Suite A, Westinghouse Hanford Company, Richland, WA.

- Location has field sampling strip charts giving approximate downward force.

WHC 1996a. H-2 drawings on microfilm. In: Microfilm. Available: WHC, 200E, MO-047, or WHC, 2900 George Washington Way, ETC-2, Westinghouse Hanford Company, Richland, WA.

- Location has drawings (including tank drawings) available on microfilm

WHC 1996b. RMCSDATE.XLS: Rotary Mode Core Sampling Spreadsheet. In: MS Excel. Available: Hanford Local Area Network (HLAN), Westinghouse Hanford Company, Richland WA.

- Spreadsheet contains detailed field sampling information for the rotary mode core sampling trucks (ie. sampling date, tank number, core number, sample number, riser number, bit type, $\mathrm{mRem} / \mathrm{hr}$, lbs. downforce, etc.)

WHC 1996c. SACS: Surveillance Analysis Computer System. In: SYBASE/Visual Basic [Mainframe]. Available: HLAN, Westinghouse Hanford Company, Richland, WA; or Tank Waste Information Network System, Pacific Northwest National Laboratory, Richland, WA.

- Database contains 200 Area tank surveillance data from both Computer Austomated Surveillance System and Tank Monitoring and Control System.

WHC 1996d. Vidon In-tank Photo Library. In: Hard copy. Available: WHC, 200E 2750E, Room D-164 File cabinets, Westinghouse Hanford Company, Richland, WA.

- Library consists of file cabinets containing folders of $8 \mathrm{X} 10$ in tank photos.

$$
\text { C }-9
$$


WHC-SD-WM-TI-744, Rev. 0

\section{Analytical Data}

Ila. Sampling of Tank Waste and Waste Types

242-A Evaporator

242-S Evaporator

242-T Evaporator

All the information in this section is documented in Process Aids 1969 - 1993. Process Aids is a consecutive compilation of laboratory memos, letters, etc. indexed by year then by subject and/or tank.

Buckingham, J. S., Interim Report III: Nitric Acid Neutralization and Concentration of Caustic Waste Solutions - 242-T Evaporator Feed, ARH-2529 (Unclassified), June 151972.

Buckingham, J. S., Nitric Acid Neutralization and Concentration of 242-T Evaporator Recycle Feed, Internal Letter to W. P. Metz, Process Aids \#00256, May 12, 1972, Atlantic Richfield Hanford Company Operations, Richland, WA.

Buckingham, J. S., Interim Processing of $Z$ Plant Wastes, Internal Letter to O. D. Erlandson, Process Aids \#00394, November 2, 1971, Atlantic Richfield Hanford Company

Operations, Richland, WA.

Buckingham, J. S., Solubility Curves of 242-T Evaporator Bottoms, Internal Letter to D. J. Larkin, Process Aids \#00083ff, November 18, 1970, Atlantic Richfield Hanford Company Operations, Richland, WA.

Buckingham, J. S. and D. A. Dodd, Nitric Acid Neutralization and Concentration of Synthetic Recycle Waste Solution, Internal Letter to D. J. Larkin, Process Aids \#00263, Jul. 17, 1972, Atlantic Richfield Hanford Company Operations, Richland, WA.

Puryear, D. A., Solubility of 242-T Evaporator Process Feed and Concentrate, Internal Letter to M. C. Fraser, Process Aids \#00088, Dec. 9, 1970, Atlantic Richfield Hanford Company Operations, Richland, WA.

Puryear, D. A. and J. S. Buckingham, Status Report on Waste Solidification Studies and Separations Chemistry Laboratory, Internal Letter to M. H. Campbell, et al., Process Aids \#00362, Jul. 23, 1971, Atlantic Richfield Hanford Company Operations, Richland, WA.

$$
\text { C - } 10
$$


WHC-SD-WM-TI-744, Rev. 0

\section{Other Equipment Related Sample Analyses}

Other Waste Types

TBP-Salt Mixtures

- All the information in this section is documented in Process Aids 1969 - 1993. Process Aids is a consecutive compilation of laboratory memos, letters, etc. indexed by year then by subject and/or tank.

Barney, G. S., Thermoanalysis of TBP-Salt Mixtures, Internal Letter to D. S. Thurman, Process Aids \#00209, Dec. 10, 1970, Richland, WA. 
WHC-SD-WM-TI-744, Rev. 0

IIb. Other - non/documented or electronic sources

ICF Kaiser Hanford (ICF KH) 1996. Kaiser Electronic: Historical Sampling Data. In: Microsoft Excel ver. 5.0. Available: Tank Waste Information Network System (TWINS), Pacific Northwest National Laboratory, Richland, WA.

- Spreadsheets contain historical sampling data for dates prior to samples available in Tank Characterization Database.

Pacific Northwest National Laboratory (PNNL) 1996. TCD: Tank Characterization Database. In: SYBASE version 4.0. Available: Tank Waste Information Network System (TWINS).

- Database contains qualified raw sampling data taken in the past few years from 222-S laboratory. A small amount of information from the 325 laboratory data is included at this time.

WHC 1996e. Extrusion Video Tapes, In: VHS. Available: 222-S Hotcell, Westinghouse Hanford Company, Richland, WA.

- Videos contain a visual presentation of the extrusion process of the samples, and the relative color of the extruded material.

WHC 1996f. Extrusion laboratory notebooks, In Hardcopy. Available: 222-S Hotcell, Westinghouse Hanford Company, Richland, WA.

- Lab notebooks contain a record of the events surrounding sample extrusion and analysis as well as some actual data.

WHC 1996g. Cal Delegard, personal file cabinet. In hard copy. Available: WHC, 200W Trailer MO-346, Room 4, Westinghouse Hanford Company, Richland, WA.

- File cabinet contains files of information on actinide solubility.

WHC 1996h. Dan Herting, personal file cabinet. In: hard copy. Available: WHC, 200W Trailer MO-346, Room 5, Westinghouse Hanford Company, Richland, WA.

- File cabinet contain files of sample analyses from tanks that Dr. Herting has worked on. 
WHC-SD-WM-TI-744, Rev. 0

\section{Combined Analytical/Non-Analytical Data}

III. Inventories from Campaign and Analytical Information

Agnew, S.F., Hanford Defined Wastes: Chemical and Radionuclide Compositions, LA-UR-942657, Rev. 2, Aug 1994, Los Alamos National Laboratory, Los Alamos, New Mexico.

- Document contains waste type summaries as well as primary chemical compound/analyte and radionuclide estimates for sludge, supernatant, and solids.

Agnew, S. F., Letter Report: Strategy for analytical data comparisons to HDW model, Letter \#: CST-4:95-sfa272, to Susan Eberlein, Sept. 28, 1995, Los Alamos National Laboratory, Los Alamos, New Mexico.

- Document contains proposed tank groups based on TLM, and statistical method for comparing analytical information to HDW predictions.

Agnew, S. F., J. Boyer, R. Corbin, T. Duran, J. FitzPatrick, K. Jurgensen, T. Ortiz, B. Young, Hanford Tank Chemical and Radionuclide Inventories: HDWModel Rev. 3, Draft, March 5, 1996, Los Alamos National Laboratory, Los Alamos, New Mexico.

- Document contains waste type summaries, primary chemical compound/analyte and radionuclide estimates for sludge, supernatant, and solids, as well as SMM, TLM, and individual tank inventory estimates.

Allen, G.K., Estimated Inventory of Chemicals Added to Underground Waste Tanks, 1944 1975, ARH-CD-601B, Mar 1976, Atlantic Richfield Hanford Company Operations, Richland, WA.

- Document contains major components for waste types, and some assumptions

Allen, G.K., Hanford Liquid Waste Inventory As Of Sept. 30, 1974, ARH-CD-229, Jan 1975, Atlantic Richfield Hanford Company Operations, Richland, WA.

- Document contains major components for waste types, and some assumptions 
Brevick, C.H., et al., Historical Tank Content Estimate for the Northeast Quadrant of the Hanford 200 Areas, WHC-SD-WM-ER-349, Mar. 9, 1995, Rev 0A, Westinghouse Hanford Company, Richland, WA.

- Document contains summary information from the supporting documents for Tank Farms A, AX, B, BX, BY, and C, as well as in-tank photo collages and the solid (including the interstitial liquid) composite inventory estimates.

Brevick, C.H., et al., Historical Tank Content Estimate for the Northwest Quadrant of the Hanford 200 Areas, WHC-SD-WM-ER-351, Apr. 3, 1995, Rev. 0, Westinghouse Hanford Company, Richland, WA.

- Document contains summary information from the supporting document for Tank Farms T, TX, and TY as well as in-tank photo collages and the solid (including the interstitial liquid) composite inventory estimates.

Brevick, C.H., et al., Historical Tank Content Estimate for the Southeast Quadrant of the Hanford 200 Areas, WHC-SD-WM-ER-350, Jul. 6, 1995, Rev. 0, Westinghouse Hanford Company, Richland, WA.

- Document contains summary information from the supporting document for Tank Farms AN, AP, AW, AY, AZ, and SY as well as in-tank photo collages and the total inventory and supernatant composite inventory estimates.

Brevick, C.H., et al, Historical Tank Content Estimate for the Southwest Quadrant of the Hanford 200 Areas, WHC-SD-WM-ER-352, Mar. 9, 1995, Rev 0A, Westinghouse Hanford Company, Richland, WA.

- Document contains summary information from the supporting document for Tank Farms S, SX, and $\mathrm{U}$ as well as in-tank photo collages and the solid (including the interstitial liquid) composite inventory estimates.

Grigsby, J. M., Ferrocyanide Waste Tank Hazard Assessment - Interim Report, WHC-SD-WMRPT-032 Rev. 0, Nov. 9, 1992, Westinghouse Hanford Company, Richland, WA.

- Document contains inventory estimates from physical and campaign data for a few constituents in ferrocyanide containing tanks and a few laboratory analysis. 
Kupfer, M. J., Interim Report: Best Basis Total Chemical and Radionuclide Inventories in Hanford Site Tank Waste, WHC-SD-WM-TI-740, Rev. B-Draft, Mar. 29, 1996, Westinghouse Hanford Company, Richland, WA.

- Document contains a global component inventory for 200 Area waste tanks, currently inventoried are 14 chemical and 2 radionuclide components.

Schmittroth, F. A., Inventories for Low-Level Tank Waste, WHC-SD-WM-RPT-164, Rev. 0, 1995, Westinghouse Hanford Company, Richland, WA.

- Document contains a global inventory based on process knowledge and radioactive decay estimations using ORIGEN2. Pu and $\mathrm{U}$ waste contributions are taken at $1 \%$ of the amount used in processes. Also compares information on Tc-99 from both ORIGEN2 and analytical data. 
IIIb. Compendium of data from other sources physical and chemical Agnew, S.F., John G. Watkin, Estimation of Limiting Solubilities for Ionic Species in Hanford Waste Tank Supernates, LAUR-94-3590, Oct 1994, Los Alamos National Laboratory, Los Alamos, New Mexico.

- Document gives solubility ranges used for key chemical and radionuclide components based on supernatant sample analyses.

Brevick, C.H., et al., Historical Tank Content Estimate for the Northeast Quadrant of the Hanford 200 Areas, WHC-SD-WM-ER-349, Mar, 9 1995, Rev. 0A, Westinghouse Hanford Company, Richland, WA.

- Document contains summary information from the supporting documents for Tank Farms A, AX, B, BX, BY, and C, as well as in-tank photo collages and the solid (including the interstitial liquid) composite inventory estimates.

Brevick, C.H., et al., Historical Tank Content Estimate for the Northwest Quadrant of the Hanford 200 Areas, WHC-SD-WM-ER-351, Apr. 3, 1995, Rev. 0, Westinghouse Hanford Company, Richland, WA.

- Document contains summary information from the supporting document for Tank Farms T, TX, and TY as well as in-tank photo collages and the solid (including the interstitial liquid) composite inventory estimates.

Brevick, C.H., et al., Historical Tank Content Estimate for the Southeast Quadrant of the Hanford 200 Areas, WHC-SD-WM-ER-350, Jul. 6, 1995, Rev. 0, Westinghouse Hanford Company, Richland, WA.

- Document contains summary information from the supporting document for Tank Farms AN, AP, AW, AY, AZ, and SY as well as in-tank photo collages and the solid (including the interstitial liquid) composite inventory estimates.

Brevick, C.H., et al, Historical Tank Content Estimate for the Southwest Quadrant of the Hanford 200 Areas, WHC-SD-WM-ER-352, Mar. 9, 1995, Rev 0A, Westinghouse Hanford Company, Richland, WA.

- Document contains summary information from the supporting document for Tank Farms S, SX, and U as well as in-tank photo collages and the solid (including the interstitial liquid) composite inventory estimates.

C -16 
Brevick, C.H., et al., Supporting Document for the Historical Tank Content Estimate for A Tank Farm, WHC-SD-WM-ER-308, Sept. 30, 1994, Rev. 0, Westinghouse Hanford Company, Richland, WA.

- Grouped here are all the supporting documents for the Historical Tank Content Estimate spanning WHC-SD-WM-ER-308 to WHC-SD-WM-ER-325. These documents contain summary tank farm and tank write-ups on historical data and solid inventory estimates as well as appendices for the data. The appendices contain the following information: App. C - Level History AutoCAD sketch, App. D - Temperature Graphs, App. E - Surface Level Graph, App. F, pg F-1 - Cascade/Drywell Chart, App. G - Riser Configuration Drawing and Table, App. I - In-Tank Photos, and App. K - Tank Layer Model Bar Chart and Spreadsheet.

Brevick, C.H., et al., Tank Waste Source Term Inventory Validation, Vol I \& II., WHC-SD-WMER-400, May 1, 1995, Rev. 0, Westinghouse Hanford Company, Richland, WA.

- Document contains a quick reference to sampling information in spreadsheet or graphical form for 23 chemicals and 11 radionuclides for all the tanks.

Hanlon, B.M., Tank Farm Surveillance and Waste Status Summary Report for November 1995, WHC-EP-0182-92, 1995, Westinghouse Hanford Company, Richland, WA.

- These documents contain a monthly summary of: fill volumes, watchlist tanks, occurrences, integrity information, equipment readings, equipment status, tank location, and other miscellaneous tank information. Grouped here are all the monthly summaries from Dec. 1947 - present, however Hanlon has only authored the monthly summaries from Nov. 1989 to present.

Husa, E.I. et al., Hanford Site Waste Storage Tank Information Notebook, WHC-EP-0625, July 1993, Westinghouse Hanford Company, Richland, WA.

- Document contains in-tank photos as well as summaries on the tank description, leak detection system, and tank status.

Husa, E. I., Hanford Waste Tank Preliminary Dryness Evaluation, WHC-SD-WM-TI-703, Rev 0., Jun. 30, 1995, Westinghouse Hanford Company, Richland, WA.

- Document gives assessment of relative dryness between tanks. 
Jungfleisch, F.M., Hanford High-Level Defense Waste Characterization - A Status Report, RHOCD-1019, July 1980, Rockwell Hanford Operations, Richland, WA.

- Document provides status information to plan outlined by G. W. Grimes, Oct 1977 containing a summary of sampling, characterization, and analysis data for the tanks sampled.

Remund, K. M., G. Chen, S. A. Hartley, J York, B. C. Simpson, Historical Tank Content Estimate (HTCE) and Sampling Estimate Comparisons, PNL-10840, Nov. 1995, Pacific Northwest Laboratory, Richland, WA.

- Document contains a statistical evaluation of the HDW inventory estimate against analytical values from 12 existing TCR reports using a select component data set.

Shelton, L. W., Chemical and Radionuclide Inventory for Single and Double Shell tanks, Internal Memo to R. M. Orme, 75520-95-007, Aug. 8, 1995, Westinghouse Hanford Company, Richland, WA.

- Memo contains an tank inventory estimate based on analytical information.

Shelton, L. W., Radionuclide Inventories for Single and Double Shell Tanks, Internal Memo \#71320-95-002, 1995, Westinghouse Hanford Company, Richland, WA.

- Memo contains an tank inventory estimate based on analytical information.

Van Vleet, R. J., Radionuclide and Chemical Inventories for the Single Shell Tanks, WHC-SDWM-TI-565, Rev. 1, 1993, Westinghouse Hanford Company, Richland, WA.

- Document contains selected sample analysis tables prior to 1993 for single shell tanks.

Van Vleet, R. J., Radionuclide and Chemical Inventories for the Double Shell Tanks, WHC-SDWM-TI-543, Rev. 1, 1993, Westinghouse Hanford Company, Richland, WA.

- Document contains selected sample analysis tables prior to 1993 for double shell tanks.

Weiss, R. L., TY Tank Farm Characterization Data, RHO-WM-TI-IP, March 1986, Rockwell Hanford Operations, Richland, WA.

-Document contains information on TY Farm waste core sampling and analysis results. 
WHC 1993. Process Aids A Compilation of Technical Letters By Process Laboratories and Technology, WHC-IP-0711-25, Westinghouse Hanford Company, Richland, WA.

- These documents contain a collection of internal memos and letters concerning tank or process sampling. Grouped here are all of the Process Aids documents from 1969 - 1993.

IIIc. Other - non/documented or electronic sources

PNNL 1996a. TWINS: Tank Waste Information Network System. In: SYBASE version 4. Available: Hanford Local Area Network (HLAN), Westinghouse Hanford Company, Richland, WA; or TCP/IP access, Pacific Northwest National Laboratory, Richland, WA.

- Database provides access to SACS, TMACS, TCD and Kaiser Electronic data. 
WHC-SD-WM-TI-744, Rev. 0

\section{Other Documented Resources}

ICF KH 1996a. ICF KH Tank Characterization Library. In hard copy. Available: ICF KH, 200E, Trailer MO-971 Room 26, Sheryl Consort: custodian, ICF Kaiser Hanford, Richland, WA.

- A resource of 200 Area tank, process campaign, reactor, and other historical records, unclassified and declassified.

WHC 1995. 222-S Laboratory RIDS: Records Inventory and Disposition Schedule. In: Harcopy. Available: In 222-S Laboratory RIDS index, WHC Archives, Westinghouse Hanford Company, Richland, WA.

- A RIDS report of the information archived for 1992-1993 from the 222-S laboratory, last printed 5/17/95. Lab notebooks may have been archived that contain pertinent information.

WHC 1996i. L.S.I.S.: Large Scale Information System, ERS DB - Engineering Release Station Database. In: Database Available: Hanford Local Area Network (HLAN), Westinghouse Hanford Company, Richland, WA.

- Database with any released document information. Most expedient to search by title and keyword for tank in question.

WHC 1996j. RMIS: Record Management Information System, Records Database. In: Database. Available: HLAN, Westinghouse Hanford Company, Richland, WA.

- Records is a database of all released documents since November 1995, which will be back loaded with previous years' data. It can be queried to find documents for any subject either in the keyword or description field.

WHC 1996k. RMIS: Record Management Information System, TFIC Database. In: Database. Available: HLAN, Westinghouse Hanford Company, Richland, WA.

- TFIC is a database of tank related reports, memos, and letters that have been optically scanned. The database can be queried to find indexed information for a tank [in the tank or description field] or information referenced to any subject either in the keyword or description field. 
WHC-SD-WM-TI-744, Rev. 0

WHC 19961. TCRC: Tank Characterization Resource Center. In: hard copy. Available: 2750E Room A-243, Ann Young: custodian, Westinghouse Hanford Company, Richland, WA.

- A resource of TWRS characterization data including: hard copy file folders of sampling data for each tank, an index of multiple tank documents folders, physical/chemical data compendiums, and studies or reports on 200 Area Tanks or Tank Waste generated by various contractors.

WHC 1996m. 209-E Waste Tanks Document Index. In: Hard copy. Available: ICF KH Library, ICF Kaiser Hanford, Richland, WA.

- An index of general and tank specific information for the 200 Area tanks.

Ogden Environmental Company, Sept. 1993. TRAC Reference Documentation at Ogden. In: Hard copy. Available: ICF KH Library, ICF Kaiser Hanford, Richland, WA.

- An index of general information used in support of Track Radioactive Components. 
WHC-SD-WM-TI-744, Rev. 0

\section{Appendix D}

200 Area Waste Tank Physical/Chemical Expected Profile Reference Checklist Sample

$$
\text { D - } 0
$$



WHC-SD-WM-TI-744, Rev. 0

\section{Appendix D \\ 200 Area Tank Waste Physical/Chemical Expected Profile Reference Checklist Sample}

Agnew, S. F., Hanford Defined Wastes HDW: Chemical and Radionuclide Compositions, LAUR-94-2657, Rev. 2.

1. Waste type summaries

2. Chemical breakdown estimates for the waste types

Agnew, S. F., R. Corbin, T. Duran, K. Jurgensen, T. Ortiz, and B. Young, WSTRS Rev. 2:

Supernatant Mixing Model (SMM) Tank Layer Model (TLM), LA-UR-94-4269, Rev. 2, Oct. 1995.

Agnew, S.F., R. A. Corbin, T. B. Duran, K. A. Jurgensen, T. P. Ortiz, and B. L. Young, Waste Status and Transaction Record Summary Reports, WHC-SD-WM-TI-614, 615, 669, and 689, Rev. 1, Jan. 26, 1996.

Allen G. K., Estimated Inventory of Chemicals Added to Underground Waste Tanks, ARH-CD$601 B$.

Allen G. K., Hanford Liquid Waste Inventory As Of Sept. 30, 1974, ARH-CD-229.

Anderson, J. D., A History of the 200 Area Tank Farms, WHC-MR-0132.

Borsheim, G. L. and B. C. Simpson, An Assessment of the Inventories of the Ferrocyanide Watchlist Tanks, WHC-SD-WM-ER-133, Rev. 0. (if applicable)

Brevick, C. H., Historical Tank Content Estimate Reports, WHC-SD-WM-ER-349 to WHC-SDWM-ER-352.

- Solid Composite Inventory Estimate from Rev. 0 and Rev. 0-A

Brevick, C. H., Supporting Documents to the Historical Tank Content Estimate Reports, WHCSD-WM-ER-308 to WHC-SD-WM-ER-325.

1. Farm Write-Up/Tank Write-Up (Farm Information)

2. Level History AutoCAD sketch (App. C)

3. Temperature Graphs (App. D)

4. Surface Level Graph (App. E)

5. Cascade/Drywell Chart (App. F, pg F-1)

6. Riser Configuration Drawing and Table (App. G)

7. In-Tank Photos (App. I)

8. Tank Layer Model Bar Chart and Spreadsheet (App. K)

D -1 
WHC-SD-WM-TI-744, Rev. 0

Hanlon, B. M., Waste Status Summary Reports, WHC-EP-0182-\#, RHO-RE-SR-\#\#, ARH-CD\#\#, HW-\#\#\#, etc.

1. Temperature of tank waste when waste first added (if available)

2. Any current tank information

Ivar, E. I., Hanford Site Waste Storage Tank Information Notebook, WHC-EP-0625.

Jungfleisch, F. M., et al., Preliminary Estimation of the Waste Inventories in Hanford Tanks Through 1980, SD-WM-TI-057, Rev. 0-A.

Lipnicki, J., Waste Tank Risers Available for Sampling, WHC-SD-WM-TI-710, Rev. 2.

WHC and RHO, Process Aids, WHC-IP-0711 Vol. 1 - 25, RHO-RE-SR-\#\#, RHO-CD-\#\#. (if no information is available on a particular waste type)

WHC, RMIS: Record Management Information System, TFIC Database, Records Database. HLAN.

WHC, TCRC: Tank Characterization Resource Center. WHC 200E 2750E Room A-243.

1. Sampling information files per tank

2. Multi-tank information files

WHC - Various Authors, Tank Characterization Plans, WHC-SD-WM-TP-\#.

WHC - Various Authors, Tank Characterization Reports, WHC-SD-WM-ER-\#\# or PNL-\#\#\#\#.

WHC, Vidon In-Tank Photo Library, WHC, 200E 2750E, Room D-164 File Cabinets.

D - 2 
WHC-SD-WM-TI-744, Rev. 0

\section{Appendix E}

\section{Physical Profile Estimate Examples}

E - 0 


\section{Appendix E \\ Physical Profile Estimate Examples}

Tank 241-BX-104 Physical Profile Estimate

\begin{tabular}{|c|l|l|l||}
\hline Segment & $\begin{array}{l}\text { Segment Elevation } \\
\text { Range (Ft. MSL) }\end{array}$ & $\begin{array}{l}\text { Physical Waste } \\
\text { Characterization }\end{array}$ & Comments \\
\hline 1 & $620.00-619.62^{\prime}$ & \multicolumn{1}{|c||}{ N/A } & Air \\
\hline 1 & $619.62-618.58^{\prime}$ & $\begin{array}{l}\text { Sludge, ranging in } \\
\text { consistency from very soft } \\
\text { to soft. Possible thin layer } \\
\text { of supernatant liquid. }\end{array}$ & $\begin{array}{l}\text { Anticipate good recovery of } \\
\text { solids. }\end{array}$ \\
\hline 1 & $618.58-618.41^{\prime}$ & $\begin{array}{l}\text { Sludge, with consistency } \\
\text { directly proportionate to } \\
\text { depth. Potentially small, } \\
\text { granular solids. }\end{array}$ & Anticipate good recovery. \\
\hline 2 & $618.41-616.83^{\prime}$ & $\begin{array}{l}\text { Sludge, with consistency } \\
\text { directly proportionate to } \\
\text { depth. Potentially small, } \\
\text { granular solids. }\end{array}$ & Anticipate good recovery. \\
\hline
\end{tabular}


WHC-SD-WM-TI-744, Rev. 0

Tank-241-U-102 Physical Profile Estimate

Push Mode Core Sampling with RMCS Truck

\begin{tabular}{|c|c|c|c|c|}
\hline Segm. & Elevation Ranges (ft) & Length(in) & Physical Waste Characteristics & Comments \\
\hline \multirow{3}{*}{1} & $638.90 \cdot 638.77$ & 1.5 & Air & Empty \\
\hline & $638.77-638.23$ & 6.5 & $\begin{array}{l}\text { Dry crust above the surface of } \\
\text { liquid/ wet sludge. Evidence of } \\
\text { liquid/wet sludge on the broken } \\
\text { spot of crust. }\end{array}$ & $\begin{array}{l}\text { Easy pentration with limited } \\
\text { recovery. Metal tape was } \\
\text { observed on the surface of the } \\
\text { waste underneath this riser. }\end{array}$ \\
\hline & $638.23 \cdot 637.32$ & 10.9 & Wet salt slurry & $\begin{array}{l}\text { Soft sludge, easy pentration. } \\
\text { Reasonable recovery }\end{array}$ \\
\hline 2 & $637.32-635.74$ & 19.0 & Wet salt slury & $\begin{array}{l}\text { Soft sludge, easy to go through. } \\
\text { Reasonable recovery }\end{array}$ \\
\hline 3 & $635.74-634.15$ & 19.0 & Wet salt slurry/cake & $\begin{array}{l}\text { Soft sludge, easy to go through. } \\
\text { Reasonable recovery }\end{array}$ \\
\hline 4 & $634.15 \cdot 632.57$ & 19.0 & Wet salt slurry/cake sludge & $\begin{array}{l}\text { More compact, with increasing } \\
\text { down-force, good recovery }\end{array}$ \\
\hline 5 & $632.57-630.99$ & 19.0 & Wet salt cake sludge & $\begin{array}{l}\text { More compact, with increasing } \\
\text { down-force, good recovery }\end{array}$ \\
\hline 6 & $630.99 \cdot 629.40$ & 19.0 & Wet salt cake sludge & $\begin{array}{l}\text { More compact, with increasing } \\
\text { down-force, good recovery }\end{array}$ \\
\hline \multirow[b]{2}{*}{7} & $629.40 \cdot 628.74$ & 7.9 & Wet salt cake sludge & $\begin{array}{l}\text { More compact, with increasing } \\
\text { down-force, good recovery }\end{array}$ \\
\hline & $628.74-627.82$ & 11.1 & $\begin{array}{l}\text { Metal waste, a dense sludge with } \\
\text { mainly sodium nitrate and also } \\
\text { include metal compound }\end{array}$ & $\begin{array}{l}\text { Dense and well compact sludge, } \\
\text { expect difficulty to drill through. } \\
\text { Reasonable recovery. }\end{array}$ \\
\hline
\end{tabular}

E - 2 
WHC-SD-WM-TI-744, Rev. 0

\section{Tank 241-S-111 Physical Profile Estimate \\ Riser 8}

\begin{tabular}{|c|c|c|c|c|}
\hline Segment \# & Inches & $\begin{array}{c}\text { Elevation Range } \\
\text { (ft. MSL) }\end{array}$ & $\begin{array}{c}\text { Waste Type } \\
\text { Characteristics }\end{array}$ & Comments \\
\hline \multirow[t]{2}{*}{1} & 11 & $637.85-638.75$ & air & \\
\hline & 8 & $637.17-637.85$ & supernatant & limited recovery \\
\hline \multirow[t]{2}{*}{2} & 9 & $636.43-637.17$ & supernatant & limited recovery \\
\hline & 10 & $635.58-636.43$ & soft wet saltcake & good recovery \\
\hline 3 & 19 & $634.00-635.58$ & soft wet saltcake & good recovery \\
\hline 4 & 19 & $632.42-634.00$ & soft wet saltcake & good recovery \\
\hline 5 & 19 & $630.83-632.42$ & soft wet saltcake & good recovery \\
\hline \multirow[t]{2}{*}{6} & 17 & $629.43-630.83$ & soft wet saltcake & good recovery \\
\hline & 2 & $629.25-629.43$ & $\begin{array}{l}\text { soft wet saltcake/sludge } \\
\text { mix }\end{array}$ & good recovery, will look like sludge \\
\hline 7 & 19 & $627.67-629.25$ & $\begin{array}{l}\text { soft wet saltcake/sludge } \\
\text { mix }\end{array}$ & good recovery, will look like sludge \\
\hline 8 & 19 & $626.08-627.67$ & $\begin{array}{l}\text { soft wet saltcake/sludge } \\
\text { mix }\end{array}$ & good recovery, will look like sludge \\
\hline \multirow[t]{2}{*}{9} & 18 & $624.50-626.08$ & \begin{tabular}{|l} 
soft wet saltcake/sludge \\
mix
\end{tabular} & good recovery, will look like sludge \\
\hline & 1 & $624.43-624.50$ & $\begin{array}{l}\text { soft wet saltcake/sludge } \\
\text { mix }\end{array}$ & good recovery, will look like sludge \\
\hline 10 & 18 & $622.92-624.43$ & $\begin{array}{l}\text { Redox Waste: soft, wet } \\
\text { sludge }\end{array}$ & $\begin{array}{l}\text { Could have interface layer in segment } \\
\text { anticipate good recovery }\end{array}$ \\
\hline 11 & 19 & $621.33-622.92$ & $\begin{array}{l}\text { Redox Waste: } \\
\text { relatively sompact, damp } \\
\text { sludge }\end{array}$ & Anticipate good recovery \\
\hline 12 & 19 & $619.75-621.33$ & $\begin{array}{l}\text { Redox Waste: compact } \\
\text { soft. wet sludge }\end{array}$ & Anticipate good recovery \\
\hline
\end{tabular}

Note: Elevation estimates based on tank center elevation of $619.43 \mathrm{ft}$. MSL. 
WHC-SD-WM-TI-744, Rev. 0

\section{1-BX-104 EXPECTED PROFILES}

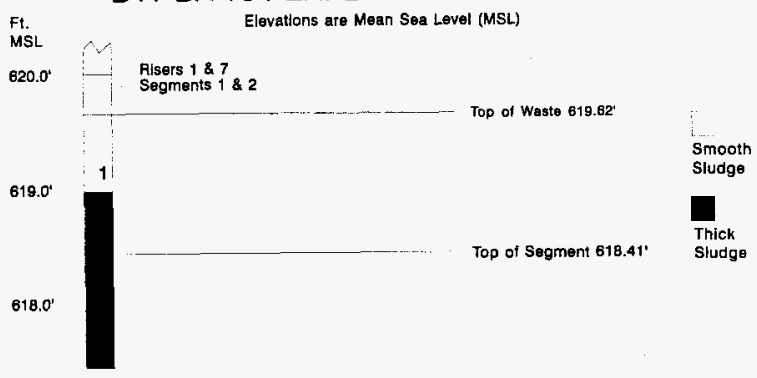

Expected Profiles

E - 4 


\section{Tank 241-U-102 Core Sample Physical Profile Estimate}

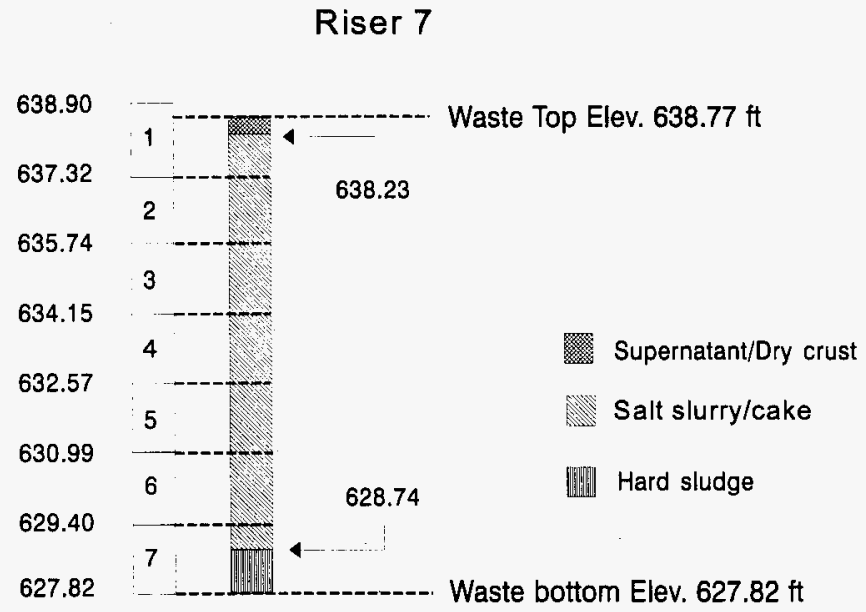

Note: The elevation was calculated based on the tank center bottom $627 \mathrm{ft}$ in mean sea level(MSL).

$$
\text { E - } 5
$$


WHC-SD-WM-TI-744, Rev. 0

\section{Tank 241-S-111 Physical Profile Estimate (Riser 8)}

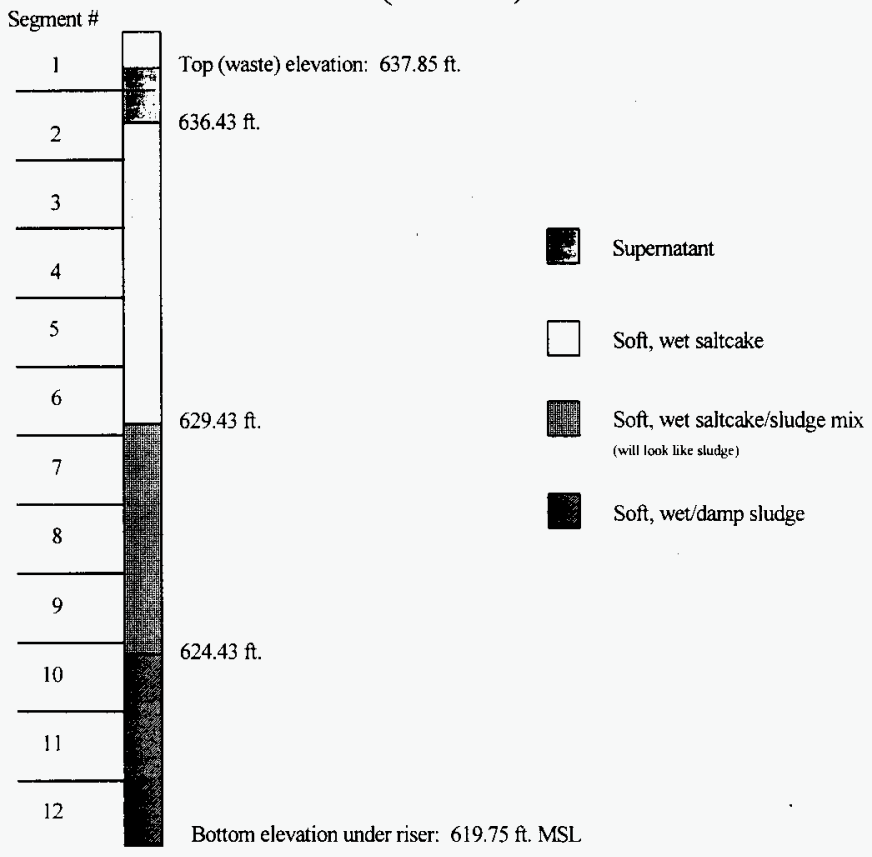

E - 6 
WHC-SD-WM-TI-744, Rev. 0

\section{Appendix F}

Chemical Profile Estimate Examples

$$
\text { F }-0
$$


WHC-SD-WM-TI-744, Rev. 0

Appendix F

Chemical Profile Estimate Examples

241-U-109 Riser 19 - Chemical Prediction

\begin{tabular}{|c|c|c|c|}
\hline Segment Number & $\begin{array}{l}\text { Segment Elevation } \\
\text { Range (f.. MSL) }\end{array}$ & Predicted Waste Layer & Major analytes/compounds \\
\hline \multirow[t]{2}{*}{1} & $640.66-641.02$ & $\mathrm{Air}$ & \\
\hline & $639.43-640.66$ & Supernatant & $\mathrm{Al}, \mathrm{CO}_{3}, \mathrm{Na}, \mathrm{NO}_{2}, \mathrm{NO}_{3}, \mathrm{OH}$ \\
\hline \multirow[t]{2}{*}{2} & $640.07-639.43$ & Supernatant & $\mathrm{AI}, \mathrm{CO}_{3}, \mathrm{Na}, \mathrm{NO}_{2}, \mathrm{NO}_{3}, \mathrm{OH}$ \\
\hline & $637.85-640.07$ & S2 Salt Slurry & $\begin{array}{l}\mathrm{Al}, \mathrm{Cl}, \mathrm{CO}_{3},{ }^{137} \mathrm{Cs}, \mathrm{F}, \mathrm{Fe}, \text { glycolate, } \\
\mathrm{K}, \mathrm{Na}, \mathrm{NO}_{2}, \mathrm{NO}_{3}, \mathrm{OH},{ }^{239} \mathrm{Pu}, \mathrm{PO}_{4}, \\
\mathrm{SO}_{4},{ }^{90} \mathrm{Sr}\end{array}$ \\
\hline 3 & $636.27-637.85$ & S2 Salt Slurry & $\begin{array}{l}\mathrm{Al}, \mathrm{Cl}, \mathrm{CO}_{33}{ }^{137} \mathrm{Cs}, \mathrm{F}, \mathrm{Fe} \text {, glycolate, } \\
\mathrm{K}, \mathrm{Na}, \mathrm{NO}_{2}, \mathrm{NO}_{3}, \mathrm{OH},{ }^{239} \mathrm{Pu}, \mathrm{PO}_{4} \\
\mathrm{SO}_{4}{ }^{90} \mathrm{Sr}\end{array}$ \\
\hline 4 & $634.69-636.27$ & S2 Salt Slurry & $\begin{array}{l}\mathrm{Al}, \mathrm{Cl}, \mathrm{CO}_{3},{ }^{137} \mathrm{Cs}, \mathrm{F}, \mathrm{Fe} \text {, glycolate, } \\
\mathrm{K}, \mathrm{Na}, \mathrm{NO}_{2}, \mathrm{NO}_{3}, \mathrm{OH},{ }^{230} \mathrm{Pu}, \mathrm{PO}_{4}, \\
\mathrm{SO}_{4},{ }^{90} \mathrm{Sr}\end{array}$ \\
\hline \multirow[t]{2}{*}{5} & $634.33-634.69$ & S2 Salt Slumy & $\begin{array}{l}\mathrm{Al}, \mathrm{Cl}, \mathrm{CO}_{3},{ }^{1.37} \mathrm{Cs}, \mathrm{F}, \mathrm{Fe} \text {, glycolate, } \\
\mathrm{K}, \mathrm{Na}, \mathrm{NO}_{2}, \mathrm{NO}_{3}, \mathrm{OH},{ }^{239} \mathrm{Pu}, \mathrm{PO}_{4}, \\
\mathrm{SO}_{4},{ }^{90} \mathrm{Sr}\end{array}$ \\
\hline & $633.10-634.33$ & S1 Saltcake & $\begin{array}{l}\mathrm{Al}, \mathrm{Cl}, \mathrm{CO}_{3}, \mathrm{CI}, \mathrm{Na}, \mathrm{NO}_{2}, \mathrm{NO}_{3}, \\
\mathrm{OH}, \mathrm{PO}_{4}, \mathrm{SiO}_{3}, \mathrm{SO}_{4},{ }^{90} \mathrm{Sr}\end{array}$ \\
\hline 6 & $631.52-633.10$ & S1 Saltcake & $\begin{array}{l}\mathrm{Al}, \mathrm{Cl}, \mathrm{CO}_{3}, \mathrm{Cr}, \mathrm{Na}, \mathrm{NO}_{2}, \mathrm{NO}_{3}, \\
\mathrm{OH}, \mathrm{PO}_{4}, \mathrm{SiO}_{3}, \mathrm{SO}_{4},{ }^{90} \mathrm{Sr}\end{array}$ \\
\hline 7 & $629.94-631.52$ & S1 Saltcake & $\begin{array}{l}\mathrm{Al}, \mathrm{Cl}, \mathrm{CO}_{3}, \mathrm{Cr}, \mathrm{Na}, \mathrm{NO}_{2}, \mathrm{NO}_{3}, \\
\mathrm{OH}, \mathrm{PO}_{4}, \mathrm{SiO}_{3}, \mathrm{SO}_{4},{ }^{90} \mathrm{Sr}\end{array}$ \\
\hline 8 & $628.35-629.94$ & S1 Saltcake & $\begin{array}{l}\mathrm{Al}, \mathrm{Cl}, \mathrm{CO}_{3}, \mathrm{Cr}, \mathrm{Na}, \mathrm{NO}_{2}, \mathrm{NO}_{3}, \\
\mathrm{OH}, \mathrm{PO}_{4}, \mathrm{SiO}_{3}, \mathrm{SO}_{4}{ }^{90} \mathrm{~S}\end{array}$ \\
\hline \multirow[t]{2}{*}{9} & $628.05-628.35$ & S1 Saltcake & $\begin{array}{l}\mathrm{Al}, \mathrm{Cl}, \mathrm{CO}_{3}, \mathrm{Cr}, \mathrm{Na}, \mathrm{NO}_{2}, \mathrm{NO}_{3}, \\
\mathrm{OH}, \mathrm{PO}_{4}, \mathrm{SiO}_{3}, \mathrm{SO}_{4},{ }^{90} \mathrm{Sr}\end{array}$ \\
\hline & $626.77-628.05$ & $\begin{array}{l}\text { Redox Cladding } \\
\text { Supernatant }\end{array}$ & $\mathrm{Al}(\mathrm{OH})_{4}, \mathrm{Na}, \mathrm{NO}_{2}, \mathrm{NO}_{3}$ \\
\hline
\end{tabular}

Note: Major analytes/compounds are based on any lab analyses and predicted constituents in each waste type from LAUR-94-2657, rev. 2.0. The list given in this column is in no way to be considered definitive since the prediction is not inclusive of all analytes that could be found in the waste tanks. This list was derived using a minimum of $0.2 \mathrm{M}$ for chemical analytes, a minimum of $2.27 \mathrm{E} 8 \mathrm{~Bq} / \mathrm{L}(6.14 \mathrm{E} 3 \mu \mathrm{Ci} / \mathrm{L})$ for major alpha emitters, a minimum of $1.2 \mathrm{E} 9 \mathrm{~Bq} / \mathrm{L}$ $(3.3 \mathrm{E} 5 \mu \mathrm{Ci} / \mathrm{L})$ for ${ }^{137} \mathrm{Cs}$, and a minimum of $8.51 \mathrm{E} 8 \mathrm{~Bq} / \mathrm{L}(2.3 \mathrm{E} 4 \mu \mathrm{Ci} / \mathrm{L})$ for ${ }^{90} \mathrm{Sr}$. 
WHC-SD-WM-TI-744, Rev. 0

241-B-203 All Risers - Chemical Prediction

\begin{tabular}{|c|c|c|c|}
\hline Segment Number & $\begin{array}{l}\text { Segment Elevation } \\
\text { Range (fL. MSL) }\end{array}$ & Predicted Waste Layer & Major analyted/compounds \\
\hline \multirow[t]{3}{*}{1} & $635.93 \cdot 636.17$ & Air & \\
\hline & $635.51-635.93$ & Supernatant & $\mathrm{Ca}, \mathrm{K}, \mathrm{Mg}, \mathrm{Na}, \mathrm{NO}_{2}, \mathrm{NO}_{3}, \mathrm{PO}_{1}, \mathrm{U}$ \\
\hline & $634.58-635.51$ & 224 Waste & $\begin{array}{l}\mathrm{Al}, \mathrm{Bi}, \mathrm{Ca}, \mathrm{CO}_{3}, \mathrm{~F}, \mathrm{Fe}, \mathrm{K}, \mathrm{La}, \mathrm{Mg}, \mathrm{Na} \\
\mathrm{NO}_{2}, \mathrm{NO}_{3}, \mathrm{OH} \text {, oxalate, } \mathrm{P}, \mathrm{PO}_{4}{ }^{239} \mathrm{Pu}\end{array}$ \\
\hline 2 & $633.00-634.58$ & 224 Waste & $\begin{array}{l}\mathrm{Al}, \mathrm{Bi}, \mathrm{Ca}, \mathrm{CO}_{3}, \mathrm{~F}, \mathrm{Fe}, \mathrm{K}, \mathrm{La}, \mathrm{Mg}, \mathrm{Na} \\
\mathrm{NO}_{2}, \mathrm{NO}_{3}, \mathrm{OH} \text {, oxalate, } \mathrm{P}, \mathrm{PO}_{4},{ }^{239} \mathrm{Pu}\end{array}$ \\
\hline 3 & $631.42-633.00$ & 224 Waste & $\begin{array}{l}\mathrm{Al}, \mathrm{Bi}, \mathrm{Ca}, \mathrm{CO}_{3}, \mathrm{~F}, \mathrm{Fe}, \mathrm{K}, \mathrm{La}, \mathrm{Mg}, \mathrm{Na} \\
\mathrm{NO}_{2}, \mathrm{NO}_{3}, \mathrm{OH} \text {, oxalate, } \mathrm{P}, \mathrm{PO}_{4},{ }^{230} \mathrm{Pu}\end{array}$ \\
\hline 4 & $629.83-631.42$ & 224 Waste & $\begin{array}{l}\mathrm{Al}, \mathrm{Bi}, \mathrm{Ca}, \mathrm{CO}_{3}, \mathrm{~F}, \mathrm{Fe}, \mathrm{K}, \mathrm{La}, \mathrm{Mg}, \mathrm{Na} \\
\mathrm{NO}_{2}, \mathrm{NO}_{3}, \mathrm{OH} \text {, oxalate, } \mathrm{P}, \mathrm{PO}_{4}{ }^{239} \mathrm{Pu}\end{array}$ \\
\hline 5 & $628.25-629.83$ & 224 Waste & $\begin{array}{l}\mathrm{Al}, \mathrm{Bi}, \mathrm{Ca}, \mathrm{CO}_{3}, \mathrm{~F}, \mathrm{Fe}, \mathrm{K}, \mathrm{La}, \mathrm{Mg}, \mathrm{Na} \\
\mathrm{NO}_{2}, \mathrm{NO}_{3}, \mathrm{OH} \text {, oxalate, } \mathrm{P}, \mathrm{PO}_{4},{ }^{239} \mathrm{Pu}\end{array}$ \\
\hline$\overline{6}$ & $626.67-628.25$ & 224 Waste & $\begin{array}{l}\mathrm{Al}, \mathrm{Bi}, \mathrm{Ca}, \mathrm{CO}_{3}, \mathrm{~F}, \mathrm{Fe}, \mathrm{K}, \mathrm{La}, \mathrm{Mg}, \mathrm{Na} \\
\mathrm{NO}_{2}, \mathrm{NO}_{3}, \mathrm{OH} \text {, oxalate, } \mathrm{P}, \mathrm{PO}_{4},{ }^{239} \mathrm{Pu}\end{array}$ \\
\hline 7 & $625.08-626.67$ & 224 Waste & $\begin{array}{l}\mathrm{Al}, \mathrm{Bi}, \mathrm{Ca}, \mathrm{CO}_{3}, \mathrm{~F}, \mathrm{Fe}, \mathrm{K}, \mathrm{La}, \mathrm{Mg}, \mathrm{Na} \\
\mathrm{NO}_{2}, \mathrm{NO}_{3}, \mathrm{OH} \text {, oxalate, } \mathrm{P}, \mathrm{PO}_{4}{ }^{219} \mathrm{Pu}\end{array}$ \\
\hline 8 & $623.50-625.08$ & 224 Waste & 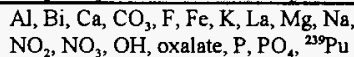 \\
\hline 9 & $621.92-623.50$ & 224 Waste & $\begin{array}{l}\mathrm{Al}, \mathrm{Bi}, \mathrm{Ca}, \mathrm{CO}_{3}, \mathrm{~F}, \mathrm{Fe}, \mathrm{K}, \mathrm{La}, \mathrm{Mg}, \mathrm{Na} \\
\mathrm{NO}_{2}, \mathrm{NO}_{3}, \mathrm{OH} \text {, oxalate, } \mathrm{P}, \mathrm{PO}_{4},{ }^{239} \mathrm{Pu}\end{array}$ \\
\hline 10 & $620.33-621.92$ & 224 Waste & $\begin{array}{l}\mathrm{AJ}, \mathrm{Bi}, \mathrm{Ca}, \mathrm{CO}_{3}, \mathrm{~F}, \mathrm{Fe}, \mathrm{K}, \mathrm{La}, \mathrm{Mg}, \mathrm{Na} \\
\mathrm{NO}_{2}, \mathrm{NO}_{3}, \mathrm{OH} \text {, oxalate, } \mathrm{P}, \mathrm{PO},{ }^{239} \mathrm{Pu}\end{array}$ \\
\hline 11 & $618.75-620.33$ & 224 Waste & $\begin{array}{l}\mathrm{Al}, \mathrm{Bi}, \mathrm{Ca}, \mathrm{CO}_{3}, \mathrm{~F}, \mathrm{Fe}, \mathrm{K}, \mathrm{La}, \mathrm{Mg}, \mathrm{Na} \\
\mathrm{NO}_{2}, \mathrm{NO}_{3}, \mathrm{OH} \text {, oxalate, } \mathrm{P}, \mathrm{PO}_{4}{ }^{239} \mathrm{Pu}\end{array}$ \\
\hline 12 & $617.17-618.75$ & 224 Waste & $\begin{array}{l}\mathrm{AJ}, \mathrm{Bi}, \mathrm{Ca}, \mathrm{CO}_{3}, \mathrm{~F}, \mathrm{Fe}, \mathrm{K}, \mathrm{La}, \mathrm{Mg}, \mathrm{Na} \\
\mathrm{NO}_{2}, \mathrm{NO}_{3}, \mathrm{OH} \text {, oxalate, } \mathrm{P}, \mathrm{PO}_{4},{ }^{239} \mathrm{Pu}\end{array}$ \\
\hline 13 & $615.58-617.17$ & 224 Waste & $\begin{array}{l}\mathrm{Al}, \mathrm{Bi}, \mathrm{Ca}, \mathrm{CO}_{3}, \mathrm{~F}, \mathrm{Fe}, \mathrm{K}, \mathrm{La}, \mathrm{Mg}, \mathrm{Na} \\
\mathrm{NO}_{2}, \mathrm{NO}_{3}, \mathrm{OH} \text {, oxalate, } \mathrm{P}, \mathrm{PO}_{4}{ }^{239} \mathrm{Pu}\end{array}$ \\
\hline 14 & $614.00-615.58$ & 224 Waste & 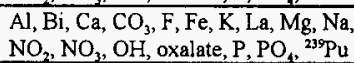 \\
\hline
\end{tabular}

Note: Major analytes/compounds are based on any lab analyses and predicted constituents in each waste type from LAUR-94-2657, rev. 2.0. The list given in this column is in no way to be considered definitive since the prediction is not inclusive of all analytes that could be found in the waste tanks. This list was derived using a minimum of $0.2 \mathrm{M}$ for chemical analytes, a minimum of $2.27 \mathrm{E} 8 \mathrm{~Bq} / \mathrm{L}(6.14 \mathrm{E} 3 \mu \mathrm{Ci} / \mathrm{L})$ for major alpha emitters, a minimum of $1.2 \mathrm{E} 9 \mathrm{~Bq} / \mathrm{L}$ (3.3 E5 $\mu \mathrm{Ci} / \mathrm{L}$ ) for ${ }^{137} \mathrm{Cs}$, and a minimum of $8.51 \mathrm{E} 8 \mathrm{~Bq} / \mathrm{L}(2.3 \mathrm{E} 4 \mu \mathrm{Ci} / \mathrm{L})$ for ${ }^{90} \mathrm{Sr}$. 
WHC-SD-WM-TI-744, Rev. 0

241-B-204 All Risers - Chemical Prediction

\begin{tabular}{|c|c|c|c|}
\hline Segment Number & $\begin{array}{l}\text { Segment Elevation } \\
\text { Range (ft. MSL) }\end{array}$ & Predicted Waste Layer & Major an lytes/compounde \\
\hline \multirow[t]{3}{*}{1} & $635.66-636.16$ & Air & \\
\hline & $635.16-635.66$ & Supernatant & $\mathrm{Al}, \mathrm{Na}, \mathrm{NO}_{2}$ \\
\hline & $634.58-635.16$ & 224 Waste & $\begin{array}{l}\mathrm{Al}, \mathrm{Bi}, \mathrm{Ca}, \mathrm{CO}_{3}, \mathrm{~F}, \mathrm{Fe}, \mathrm{K}, \mathrm{La}, \mathrm{Na} \\
\mathrm{NO}_{2}, \mathrm{NO}_{3}, \mathrm{OH} \text {, oxalate, }{ }^{299} \mathrm{Pu}, \mathrm{Sr}\end{array}$ \\
\hline 2 & $633.00-634.58$ & 224 Waste & $\begin{array}{l}\mathrm{Al}, \mathrm{Bi}, \mathrm{Ca}, \mathrm{CO}_{3}, \mathrm{~F}, \mathrm{Fe}, \mathrm{K}, \mathrm{La}, \mathrm{Na} \\
\mathrm{NO}_{2}, \mathrm{NO}_{3}, \mathrm{OH} \text {, oxalate, }{ }^{239} \mathrm{Pu}, \mathrm{Sr}\end{array}$ \\
\hline 3 & $631.42-633.00$ & 224 Waste & $\begin{array}{l}\mathrm{Al}, \mathrm{Bi}, \mathrm{Ca}, \mathrm{CO}_{3}, \mathrm{~F}, \mathrm{Fe}, \mathrm{K}, \mathrm{La}, \mathrm{Na} \\
\mathrm{NO}_{2}, \mathrm{NO}_{3}, \mathrm{OH} \text {, oxalate, }{ }^{239} \mathrm{Pu}, \mathrm{Sr}\end{array}$ \\
\hline 4 & $629.83-631.42$ & 224 Waste & $\begin{array}{l}\mathrm{Al}, \mathrm{Bi}, \mathrm{Ca}, \mathrm{CO}_{3}, \mathrm{~F}, \mathrm{Fe}, \mathrm{K}, \mathrm{La}, \mathrm{Na} \\
\mathrm{NO}_{2}, \mathrm{NO}_{3}, \mathrm{OH} \text {, oxalate, }{ }^{239} \mathrm{Pu}, \mathrm{Sr}\end{array}$ \\
\hline 5 & $628.25-629.83$ & 224 Waste & $\begin{array}{l}\mathrm{Al}, \mathrm{Bi}, \mathrm{Ca}, \mathrm{CO}_{3}, \mathrm{~F}, \mathrm{Fe}, \mathrm{K}, \mathrm{La}, \mathrm{Na} \\
\mathrm{NO}_{2}, \mathrm{NO}_{3}, \mathrm{OH} \text {, oxalate, }{ }^{239} \mathrm{Pu}, \mathrm{Sr}\end{array}$ \\
\hline 6 & $626.67-628.25$ & 224 Waste & $\begin{array}{l}\mathrm{Al}, \mathrm{Bi}, \mathrm{Ca}, \mathrm{CO}_{3}, \mathrm{~F}, \mathrm{Fe}, \mathrm{K}, \mathrm{La}, \mathrm{Na} \\
\mathrm{NO}_{2}, \mathrm{NO}_{3}, \mathrm{OH}, \text { oxalate, }{ }^{239} \mathrm{Pu}, \mathrm{Sr}\end{array}$ \\
\hline 7 & $625.08-626.67$ & 224 Waste & $\begin{array}{l}\mathrm{Al}, \mathrm{Bi}, \mathrm{Ca}, \mathrm{CO}_{3}, \mathrm{~F}, \mathrm{Fe}, \mathrm{K}, \mathrm{La}, \mathrm{Na}, \\
\mathrm{NO}_{2}, \mathrm{NO}_{3}, \mathrm{OH} \text {, oxalate, }{ }^{239} \mathrm{Pu}, \mathrm{Sr}\end{array}$ \\
\hline 8 & $623.50-625.08$ & 224 Waste & $\begin{array}{l}\mathrm{Al}, \mathrm{Bi}, \mathrm{Ca}, \mathrm{CO}_{3}, \mathrm{~F}, \mathrm{Fe}, \mathrm{K}, \mathrm{La}, \mathrm{Na} \text {, } \\
\mathrm{NO}_{2}, \mathrm{NO}_{3}, \mathrm{OH} \text {, oxalate, }{ }^{239} \mathrm{Pu}, \mathrm{Sr}\end{array}$ \\
\hline 9 & $621.92-623.50$ & 224 Waste & $\begin{array}{l}\mathrm{Al}, \mathrm{Bi}, \mathrm{Ca}, \mathrm{CO}_{3}, \mathrm{~F}, \mathrm{Fe}, \mathrm{K}, \mathrm{La}, \mathrm{Na}, \\
\mathrm{NO}_{2}, \mathrm{NO}_{3}, \mathrm{OH} \text {, oxalate, }{ }^{239} \mathrm{Pu}, \mathrm{Sr}\end{array}$ \\
\hline 10 & $620.33-621.91$ & 224 Waste & $\begin{array}{l}\mathrm{Al}, \mathrm{Bi}, \mathrm{Ca}, \mathrm{CO}_{3}, \mathrm{~F}, \mathrm{Fe}, \mathrm{K}, \mathrm{La}, \mathrm{Na} \\
\mathrm{NO}_{2}, \mathrm{NO}_{3}, \mathrm{OH} \text {, oxalate, }{ }^{239} \mathrm{Pu}, \mathrm{Sr}\end{array}$ \\
\hline 11 & $618.75-620.33$ & 224 Waste & $\begin{array}{l}\mathrm{Al}, \mathrm{Bi}, \mathrm{Ca}, \mathrm{CO}_{3}, \mathrm{~F}, \mathrm{Fe}, \mathrm{K}, \mathrm{La}, \mathrm{Na} \\
\mathrm{NO}_{2}, \mathrm{NO}_{3}, \mathrm{OH} \text {, oxalate, }{ }^{239} \mathrm{Pu}, \mathrm{Sr}\end{array}$ \\
\hline 12 & $617.16-618.75$ & 224 Waste & $\begin{array}{l}\mathrm{Al}, \mathrm{Bi}, \mathrm{Ca}, \mathrm{CO}_{3}, \mathrm{~F}, \mathrm{Fe}, \mathrm{K}, \mathrm{La}, \mathrm{Na}, \\
\mathrm{NO}_{2}, \mathrm{NO}_{3}, \mathrm{OH} \text {, oxalate, }{ }^{239} \mathrm{Pu}, \mathrm{Sr}\end{array}$ \\
\hline 13 & $615.58-617.16$ & 224 Waste & $\begin{array}{l}\mathrm{Al}, \mathrm{Bi}, \mathrm{Ca}, \mathrm{CO}_{3}, \mathrm{~F}, \mathrm{Fe}, \mathrm{K}, \mathrm{La}, \mathrm{Na}, \\
\mathrm{NO}_{2}, \mathrm{NO}_{3}, \mathrm{OH} \text {, oxalate, }{ }^{239} \mathrm{Pu}, \mathrm{Sr}\end{array}$ \\
\hline 14 & $614.00-615.58$ & 224 Waste & $\begin{array}{l}\mathrm{Al}, \mathrm{Bi}, \mathrm{Ca}, \mathrm{CO}_{3}, \mathrm{~F}, \mathrm{Fe}, \mathrm{K}, \mathrm{La}, \mathrm{Na}, \\
\mathrm{NO}_{2}, \mathrm{NO}_{3}, \mathrm{OH} \text {, oxalate, }{ }^{239} \mathrm{Pu}, \mathrm{Sr}\end{array}$ \\
\hline
\end{tabular}

Note: Major analytes/compounds are based on any lab analyses and predicted conistituents in each waste type from LAUR-94-2657, rev. 2.0. The list given in this column is in no way to be considered definitive since the prediction is not inclusive of all analytes that could be found in the waste tanks. This list was derived using a minimum of $0.2 \mathrm{M}$ for chemical analytes, a minimum of $2.27 \mathrm{E} 8 \mathrm{~Bq} / \mathrm{L}(6.14 \mathrm{E} 3 \mu \mathrm{Ci} / \mathrm{L})$ for major alpha emitters, a minimum of $1.2 \mathrm{E} 9 \mathrm{~Bq} / \mathrm{L}$ $(3.3 \mathrm{E} 5 \mu \mathrm{Ci} / \mathrm{L})$ for ${ }^{137} \mathrm{Cs}$, and a minimum of $8.51 \mathrm{E} 8 \mathrm{~Bq} / \mathrm{L}(2.3 \mathrm{E} 4 \mu \mathrm{Ci} / \mathrm{L})$ for ${ }^{90} \mathrm{Sr}$. 


\section{DISTRIBUTION SHEET}

\begin{tabular}{|c|c|c|c|c|c|}
\hline \multirow{2}{*}{$\begin{array}{l}\text { To } \\
\text { Distribution }\end{array}$} & \multirow{2}{*}{\multicolumn{3}{|c|}{$\begin{array}{l}\text { From } \\
\text { L. J. Fergestrom }\end{array}$}} & \multicolumn{2}{|l|}{ Page 1 of 1} \\
\hline & & & & \multicolumn{2}{|c|}{ Date $4 / 29 / 96$} \\
\hline \multicolumn{4}{|l|}{ Project Title/Work Order } & \multicolumn{2}{|c|}{ EDT No. 615271} \\
\hline \multicolumn{4}{|c|}{$\begin{array}{l}\text { WHC-SD-WM-TI-744, Rev. 0: Methodology for Completing Hanford } 200 \\
\text { Area Tank Waste Physical/Chemical Profile Est imations }\end{array}$} & \multicolumn{2}{|l|}{ ECN No. } \\
\hline Name & MSIN & $\begin{array}{c}\text { Text } \\
\text { With All } \\
\text { Attach. }\end{array}$ & Text Only & $\begin{array}{l}\text { Attach./ } \\
\text { Appendix } \\
\text { Only }\end{array}$ & $\begin{array}{l}\text { EDT/ECN } \\
\text { Only }\end{array}$ \\
\hline
\end{tabular}

\section{ICF Kaiser Hanford Company}

T. J. Kunthara

53-10 . X

Westinghouse Hanford Company

M. R. Adams

J. H. Baldwin

R2-12 X

D. L. Banning

K. E. Bell

C. J. Benar

T. M. Brown

L. L. Buckley

J. M. Conner

S. J. Eberlein

$\mathrm{R} 2-12$

R2-12

R2-12

R2-12

R2-12

$\mathrm{R} 2-12$

R2-12

B. F. Eggers

R2-12

R2-12

J. G. Field

R2-12

C. L. Homi

T. A. Hu

$\mathrm{R} 2-12$

R2-12

J. W. Hunt

L. Jensen

J. Jo

N. W. Kirch

J. G. Kristofzski

A. A. Kruger

M. J. Kupfer

D. J. McCain

$\mathrm{R} 2-12$

R2-12

R2-12

R2-11

R2-12

R2-12

H5-27

R2-12

L. M. Sasaki

J. B. Schaffer

R. D. Schreiber

B. C. Simpson

R. R. Thompson

W. D. Winkelman

A. E. Young

R2-12

R2-12

R2-12

R2-12

R2-12

R2-12

R2-12

$x$

Los Alamos Technical Associates
A. P. Mouse 1
S7- 12
$x$

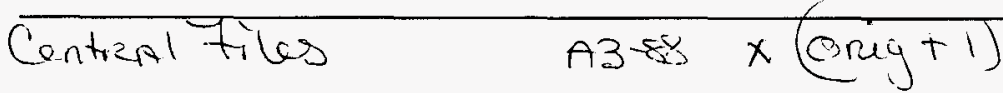

